A TWO-DIMENSIONAL, FINITE-DIFFERENCE MODEL OF THE HIGH PLAINS AQUIFER IN SOUTHERN SOUTH DAKOTA

By K. E. Kolm and H. L. Case, III

U.S. GEOLOGICAL SURVEY

Water-Resources Investigations Report 83-4175

Lakewood, Colorado

1983 
UNITED STATES DEPARTMENT OF THE INTERIOR

JAMES G. WATT, Secretary

GEOLOGICAL SURVEY

Dallas L. Peck, Director

For additional information write to:

Regional Hydrologist

U.S. Geological Survey Water Resources Division, Central Region

Box 25046, Mail Stop 406

Denver Federal Center

Lakewood, CO 80225
Copies of this report can be purchased from:

Open-File Services Section Western Distribution Branch U.S. Geological Survey Box 25425, Federal Center Lakewood, CO 80225

(Telephone: [303] 234-5888) 


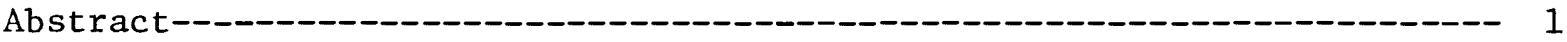

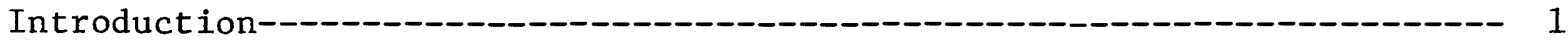

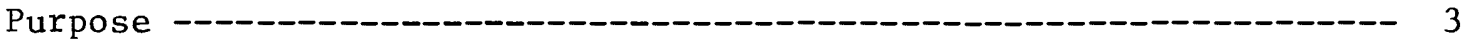

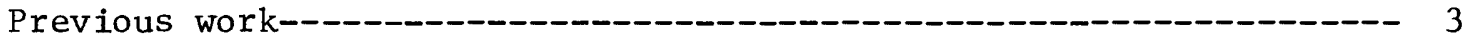

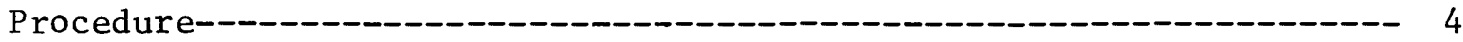

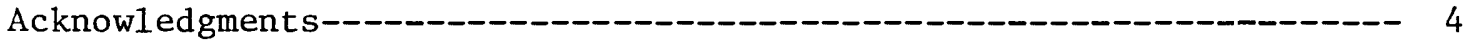

Geologic setting------- - - - - - - - - -

Aquifer characteristics-- - - - - - - - - - - - - - - - - - - - - -

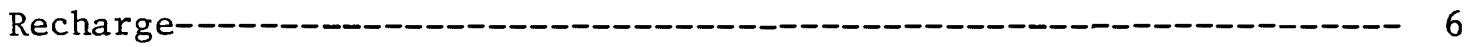

Potentiometric surface--

Discharge--------- - - - - - -

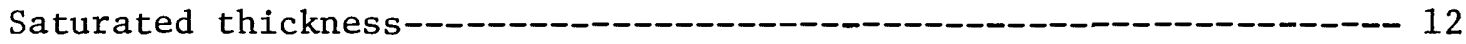

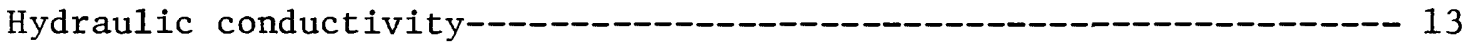

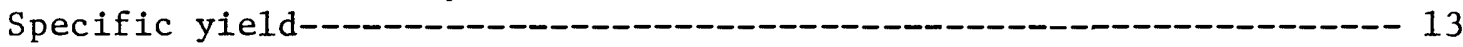

Model simulation----- - -

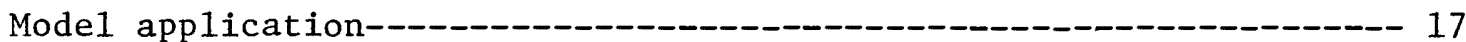

Conceptual model--_----- -

Data preparation-----

Grid geometry-- 18

Boundaries, recharge, and evapotranspiration-----_--------- 18

Model calibration results-

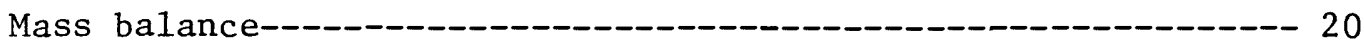

Potentiometric surface---

Boundary conditions---

Sensitivity analysis--

Hydraulic conductivity--

Recharge rates---

Boundaries----

Summary and conclusions--

Selected references--

\section{ILLUSTRATIONS}

Figures 1-4. Maps showing:

1. High Plains aquifer in the western United States, location of study area in southern South Dakota, and location of model area that extends into northern Nebraska--_-_-_-_-_-_-_-_-_-_-_-_-_-

2. Distribution of soil types in southern South Dakota and northern Nebraska--_-_- 7

3. Normal annual precipitation and mean Class A pan evaporation in the High Plains in the western United States---_-_-_-

4. Potentiometric surface of the High Plains aquifer in southern South Dakota and northern Nebraska, 1980 


\section{CONTENTS}

Page

Figure 5. Schematic geohydrologic section through the High Plains aquifer in southern South Dakota and northern

Nebraska-_-_-_-_-_-_-_-_- 11

6-10. Maps of southern South Dakota and northern Nebraska showing:

6. Saturated thickness of the High Plains aquifer----- 14

7. Hydraulic conductivity of the High Plains aquifer--- 15

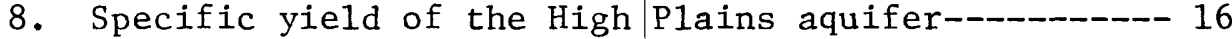

9. Grid geometry and location of model boundaries----- 19

10. Mode1-simulated potentiometric surface of the High

Plains aquifer-_-_-_- 22

11. Graph showing comparison between computed and observed heads for the calibrated model of the High Plains aquifer in southern South Dakota and northern Nebraska- 23

12. Map showing residual (difference between computed and observed) potentiometric heads for the High Plains aquifer in southern South Dakota and northern Nebraska- 24

13. Graphs showing sensitivity of the model to changes in recharge rate and hydraulic conductivity noted in the comparisons between computed and observed heads for the High Plains aquifer in southern South Dakota and northern Nebraska:

A. Hydraulic conductivity increased by 33 percent--- 27

B. Hydraulic conductivity decreased by 33 percent--- 28

C. Recharge increased by 33 percent-_-_- 29

D. Recharge decreased by 33 percent-_-_-_- 30

TABLES

Page

Table 1. General stratigraphy of the High Plains aquifer----------- 5

2. Properties of soil types-- 8 
CONVERSION TABLE

Multiply inch-pound unit

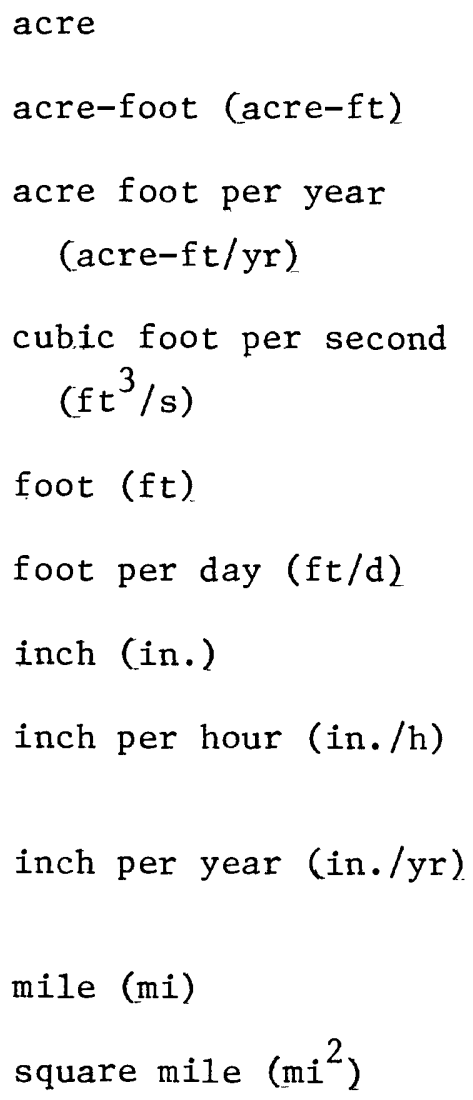

By
0.4047
1,233
1,233
0.0232
0.3048
0.3048
25.40
25.40
25.40
1.609
2.559

To obtain metric unit

hectare

cubic meter $\left(\mathrm{m}^{3}\right)$

cubic meter per year $\left(m^{3} / y r\right)$

cubic meter per second $\left(\mathrm{m}^{3} / \mathrm{s}\right)$

meter (m)

meter per day $(\mathrm{m} / \mathrm{d})$

millimeter (mm)

millimeter per hour $(\mathrm{mm} / \mathrm{h})$

millimeter per year (mm/yr)

kilometer ( $\mathrm{km})$

square kilometer $\left(\mathrm{km}^{2}\right)$ 


\title{
A TWO-DIMENSIONAL, FINITE-DIFFERENCE MODEL OF THE HIGH PLAINS AQUIFER IN SOUTHERN SOUTH DAKOTA
}

\author{
By K. E. Kolm and H. L. Case, III
}

\section{ABSTRACT}

The High Plains aquifer is the principal source of water for irrigation, industry, municipalities, and domestic use in south-central South Dakota. The aquifer, composed of upper sandstone units of the Arikaree Formation, and the overlying Ogallala and Sand Hills Formations, was simulated using a twodimensiona1, finite-difference computer model. Estimated recharge of 1.3 to 1.8 inches per year by direct infiltration of precipitation is about 8 percent of the annual precipitation across the region. Ground water moves from the south-central part of the study area to discharge to streams that are in hydraulic connection with the aquifer. Discharge also occurs as seeps and springs along the western, northern, and eastern aquifer boundaries.

The following ranges of values for aquifer properties were determined or estimated: saturated thickness, 0 to 600 feet; hydraulic conductivity, 10 to 160 feet per day; and specific yield, 0 to 25 percent. Because the depth of the local and intermediate flow systems is small compared to the extent of the regional aquifer system, vertical flow was assumed to be negligible and the aquifer was simulated in two dimensions.

A model grid with variable spacing was alined in an east-west and northsouth direction. Constant-head boundaries were used to simulate discharge and recharge in areas along the aquifer perimeter. Leaky river nodes were used to simulate streams hydraulically connected with the aquifer. The model was calibrated by simulating steady-state conditions.

The maximum difference between computed and observed heads was less than 60 feet ( 1 - to 4-percent error). Two-thirds of the computed heads were within 26 feet of the observed values (3-percent error). The estimated saturated thickness computed from simulated heads was within 25-percent error of the known saturated thickness for 95 percent of the study area.

\section{INTRODUCTION}

The High Plains aquifer, which covers approximately $174,000 \mathrm{mi}^{2}$ in eight western States ( $f i g .1$ ), consists of surficial Tertiary and Quaternary geologic units (Weeks, 1978; Weeks and Gutentag, 1981). These units provide the principal water supply for irrigation, industry, municipalities, and 


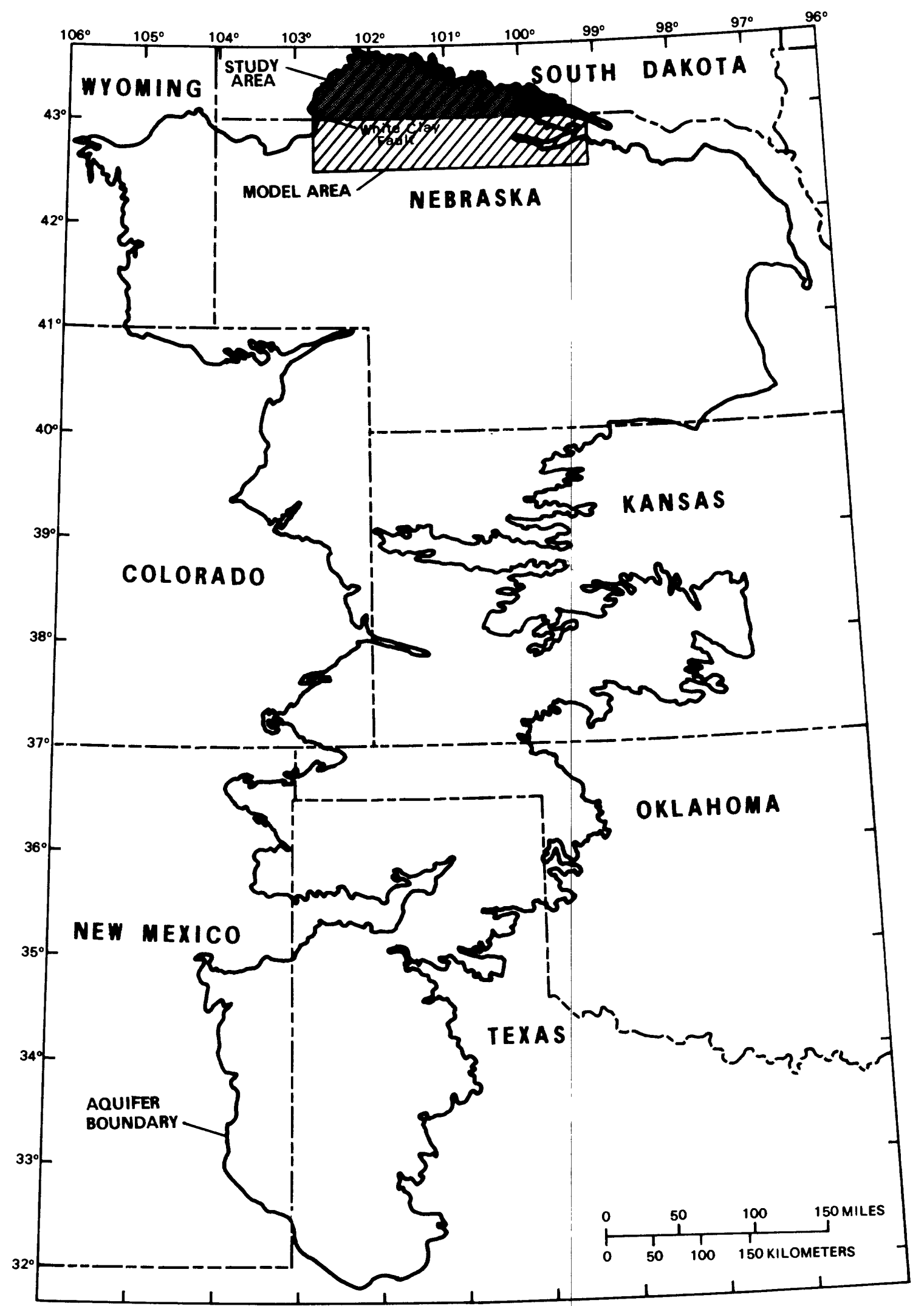

Figure 1.--High Plains aquifer in the western United States, location of study area in southern South Dakota, and location of model area that extends into northern Nebraska. 
domestic use in this region; therefore, a knowledge of the characteristics and volume of water available in the High Plains aquifer is necessary for manaing this resource.

The 5,290-mi ${ }^{2}$ study area of the southern South Dakota part of the High Plains aquifer system, located between $43^{\circ}$ and $44^{\circ}$ latitude and $99^{\circ}$ and $103^{\circ}$ longitude (fig. 1), is relatively undeveloped. About 11,100 acres of irrigated cropland account for the dominant use of water in the South Dakota High Plains aquifer area (Heimes and Luckey, 1982). In addition, most smal1town and domestic wells obtain water from these surficial geologic units. Presently, water-level changes in South Dakota are less than $10 \mathrm{ft}$ (Luckey and others, 1981). To remove the potential effects of the southern boundary on the simulated results in the study area, the southern boundary of the computer model was extended into part of the Nebraska area, although the ground-water movement in the Nebraska area is beyond the scope of this study.

\section{Purpose}

The objectives of this study were:

1. To collect, synthesize, and interpret geologic and hydrologic data on the aquifer in the southern South Dakota area;

2. To evaluate, by digital-computer-model simulation, values assigned to the aquifer parameters; and

3. To evaluate the sensitivity of the calibrated digital-computer model to changes in magnitude of the selected hydrologic parameters.

Results of this study are, therefore, applicable to solving potential waterresource management problems in the southern South Dakota and northern Nebraska model area.

\section{Previous Work}

During 1978, the U.S. Geological Survey began a 5-year study of the High Plains regional aquifer system to evaluate and simulate the effects of its ground-water development (Weeks, 1978). A plan of study for the High Plains regional aquifer system analysis (Weeks, 1978) and numerous maps describing the High Plains aquifer have resulted: 1978 water table (Gutentag and Weeks, 1980); bedrock geology, altitude of aquifer base, and 1980 saturated thickness (Weeks and Gutentag, 1981); water-level and saturated-thickness changes, predevelopment to 1980 (Luckey and others, 1981); dissolved solids and sodium in ground water (Krothe and others, 1982); and several High Plains studies concerning water quality (Feder and Krothe, 1981; Krothe and Oliver, 1982; Krothe and others, 1982); hydrologic parameters (Gutentag and Weeks, 1981); and consumptive water use (Heimes and Luckey, 1980; Heimes and Luckey, 1982). Many of these maps and reports include a regional perspective of the High Plains aquifer characteristics located in southern South Dakota. 


\section{Procedure}

Data pertaining to the geology and hydrology of the study area were obtained from Federal, State, and local agencies. Geologic information included stratigraphy, structure, areal extent of the aquifer, soil types, and distribution of unconsolidated materials covering the aquifer surface. Information pertaining to surface hydrology included precipitation, evaporation, vegetation communities (for obtaining estimates of evapotranspiration), and the location of springs and streams. Subsurface hydrologic data, derived from test drilling, laboratory studies, pumpage, and wells, included porosity, hydraulic conductivity, saturated thickness, water levels, and specific yield.

The geologic and hydrologic data were synthesized, contoured, digitized, and entered into the two-dimensional, finite-difference model for unconfinedaquifer simulation. Since the boundary of the model area was extended into northern Nebraska, geologic and hydrologic data were digitized and entered into the model from Nebraska maps prepared in a separate study by Pettijohn and Chen (1982). The model was calibrated for steady-state conditions by estimating and adjusting various hydrologic characteristics, such as transmissivities and recharge, to minimize differences between the potentiometric surfaces made from observed and simulated water levels. A sensitivity analysis was completed to evaluate the response of the model to hydraulicparameter variations during simulation.

\section{Acknowledgments}

The authors wish to thank the tribal councils of the Pine Ridge and Rosebud Reservations for allowing test drilling on their lands. Thanks are also due to the South Dakota Department of Water and Natural Resources for water-level information, and to Brian Nelson, student, South Dakota School of Mines and Technology, for helping with data compilation.

\section{GEOLOGIC SETTING}

The general stratigraphy of the High Plains aquifer was summarized by Gutentag and Weeks (1980) and Weeks and Gutentag (1981) (table 1). In southern South Dakota and northern Nebraska, the High Plains aquifer consists, in ascending order, of the upper sandstone units of the Arikaree Formation, the Ogallala Formation, the Sand Hills Formation, and any terrace or alluvial deposits, all of which are hydraulically connected (Rahn and Paul, 1975; Weeks and Gutentag, 1981).

The Arikaree Formation, called the Rosebud Formation by Harksen and MacDonald (1969), consists of moderately indurated, pink-colored shale, siltstone, and sandstone (Rahn and Paul, 1975): The Arikaree shale, when present, is relatively impermeable (E11is and others, 1972); the shale defines the lower boundary of the High Plains aquifer where its thickness is $60 \mathrm{ft}$ or greater. The Arikaree Formation, where saturated, comprises 
Table 1.-General stratigraphy of the Iigh Plains aquifer

[Modifled from Weeks and Gutentag, 1981]

\begin{tabular}{|c|c|c|c|c|}
\hline System & Series & Geologic unit & $\begin{array}{l}\text { Thickness, } \\
\text { In feet }\end{array}$ & Physical character \\
\hline \multirow{4}{*}{ 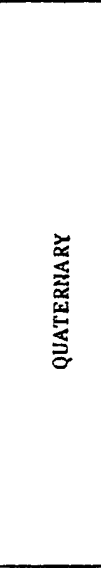 } & \multirow{3}{*}{ 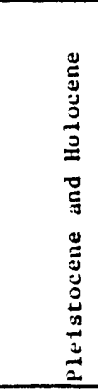 } & $\begin{array}{l}\text { Terrace and } \\
\text { valley-f1l1 } \\
\text { deposits }\end{array}$ & 0 to 60 & $\begin{array}{l}\text { Stream-lain deposits of gravel, sand, silt, and clay } \\
\text { associated with the most recent cycle of erosion } \\
\text { and depositlon along present streams. Forms part } \\
\text { of High Plains aquifer where hydraulically connected } \\
\text { to underlying Quaternary and Tertiary deposits. }\end{array}$ \\
\hline & & $\begin{array}{l}\text { Sand Hills } \\
\text { Formation }\end{array}$ & 0 to 300 & $\begin{array}{l}\text { Fine to medium sand with small amounts of clay, silt, } \\
\text { and coarse sand formed Into hills and rfdges by the } \\
\text { wind. Forms part of High Plains aquifer where sat- } \\
\text { urated. }\end{array}$ \\
\hline & & Loess & 0 to 250 & $\begin{array}{l}\text { Silt with lesser amounts of very fine sand and slay } \\
\text { deposited as windblown dust. }\end{array}$ \\
\hline & 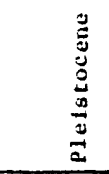 & $\begin{array}{l}\text { Alluvial } \\
\text { deposits }\end{array}$ & 0 to 550 & $\begin{array}{l}\text { Stream-lain deposits of gravel, sand, silt, and clay } \\
\text { locally cemented by calcium carbonate into callche } \\
\text { or mortar beds. Forms part of High Plains aquifer } \\
\text { where hydraulically connected laterally or verti- } \\
\text { cally to Tertiary deposits. }\end{array}$ \\
\hline \multirow{3}{*}{ 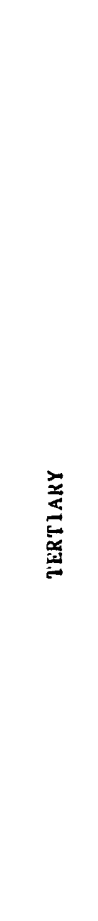 } & \multirow{2}{*}{ 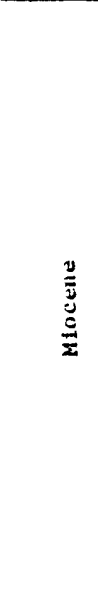 } & $\begin{array}{l}\text { Ogallala } \\
\text { Eormation }\end{array}$ & 0 to 700 & $\begin{array}{l}\text { Poorly sorted clay, silt, sand, and gravel, generally } \\
\text { unconsolidaced; forms caliche layers or mortar } \\
\text { beds when cemented by calclum carbonate. Includes } \\
\text { units equivelent to the locally-used terms "Ash } \\
\text { Hollow," "Ximball," "Sidney Gravel," and "Valentine" } \\
\text { Members or Formations assigned to the Ogallala For- } \\
\text { mation or "Group," and nelmore and Laverne Formations. } \\
\text { Ogallala comprises large part of High Plains aquifer } \\
\text { where saturated. }\end{array}$ \\
\hline & & Arikaree & a to 1,000 & $\begin{array}{l}\text { Predominately massive very flne- to fine-grained sand- } \\
\text { stone with localized beds of volcanic ash, silty } \\
\text { sand, siltstone, claystone, sandy clay, limestone, } \\
\text { marl, (and) mortar beds, and shale. Includes units } \\
\text { agsigned to the Hemingford Group of Lugn (1933), } \\
\text { Marsland Formation, Rosebud Formation used In South } \\
\text { Daikota by Harksen and Macdonald (1969), and Sheep } \\
\text { Creek Formation. Also Includes units equivalent to } \\
\text { Gering Formation, Harrison Sandstone, and Monroe } \\
\text { Creek Sandstone. Forms part of the High Plains } \\
\text { 3quifer. }\end{array}$ \\
\hline & $\begin{array}{l}\stackrel{2}{3} \\
\stackrel{0}{0} \\
\stackrel{0}{0}\end{array}$ & $\begin{array}{l}\text { White RIver } \\
\text { Group }\end{array}$ & 0 to 700 & $\begin{array}{l}\text { Opper unit, Brule Formation, predominately massive } \\
\text { siltstone containing sandstone beds and channel } \\
\text { deposits of sandstone with localized lenticular } \\
\text { beds of volcantc ash, claystone, and fine sand. } \\
\text { The Brule Formation.1s considered part of the High } \\
\text { Plains aquifer only where it contains saturated sand- } \\
\text { stones or interconnected fractures, Lower unit, } \\
\text { Chadron Formation, mainly consists of varicolored, } \\
\text { benzonitic, loosely to moderately cemented clay and } \\
\text { silt that contains channel deposits of sandstone } \\
\text { and conglomerate. }\end{array}$ \\
\hline
\end{tabular}


the major part of the High Plains aquifer in the northern and western parts of the study area.

The Ogallala Formation, which originally was divided into two formations: Valentine and overlying Ash Hollow (Sevon, 1960), is now treated as one geologic unit (Harksen and MacDonald, 1969; E1lis and others, 1972; Rahn and Paul, 1975). This formation consists of a poorly indurated, noncalcareous, medium-sorted, medium-grained, greenish-colored, pure quartz sandstone. Volcanic ash, which has weathered to clay, is locally present (Rahn and Pau1, 1975). The Ogallala Formation, where saturated, comprises a major part of the High Plains aquifer in the southern part of the study area.

The Sand Hills Formation consists of an unconsolidated, fine- to mediumgrained, brown quartz eolian dune sand with some clay and silt (Rahn and Pau1, 1975; Weeks and Gutentag, 1981). This unit, where saturated, forms the upper part of the High Plains aquifer in the south-central part of the study area.

Several unconsolidated, Quaternary terrace and valley-fill (alluvium) deposits, consisting of gravel, sand, silt, and clay, are located throughout the study area. These deposits are assumed to function as small, perchedaquifer systems, except where the High Plains aquifer discharges water into these systems. For the purposes of the ground-water modeling, these areas of hydraulic connection were treated as discharge areas.

The geologic structure of the Arikaree, Ogallala, and Sand Hills Formations in the study area is that of flat-lying strata (dipping less than $1^{\circ}$ ). One structural discontinuity, the White clay fault, is present in the southwestern part of the study area (fig. 1). The maximum normal displacement associated with the upthrown (south) side is approximately $500 \mathrm{ft}$ (Dunham, 1961). Several major lineaments also have been observed in the study area; however, no associated fault movement or hydrologic effects have been detected.

Soil types mapped in the study area (fig. 2, table 2) vary from those of silty composition, located in the uplands, to those of sandy composition in some uplands and in the sand dunes. Average hydraulic conductivity (inches per hour) of the soils ranges from 0.3 to 0.8 (silt) to 5.0 to 10.0 (sand), and the average specified yield (or effective porosity of the soil) ranges from 0.04 to 0.09 (sand) to 0.16 to 0.19 (loam, silty loam, and silt) (Luckey and others, U.S. Geological Survey, written commun., 1983). The southern part of the study area consists primarily of very permeable sand and sandy-loam soils, whereas the northern part consists mostly of moderately permeable loam and silty-loam soils (fig. 2).

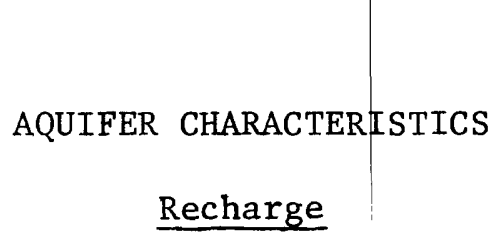

The High Plains aquifer in southern South Dakota is recharged primarily by infiltration of precipitation through soils (Rahn and Paul, 1975). 


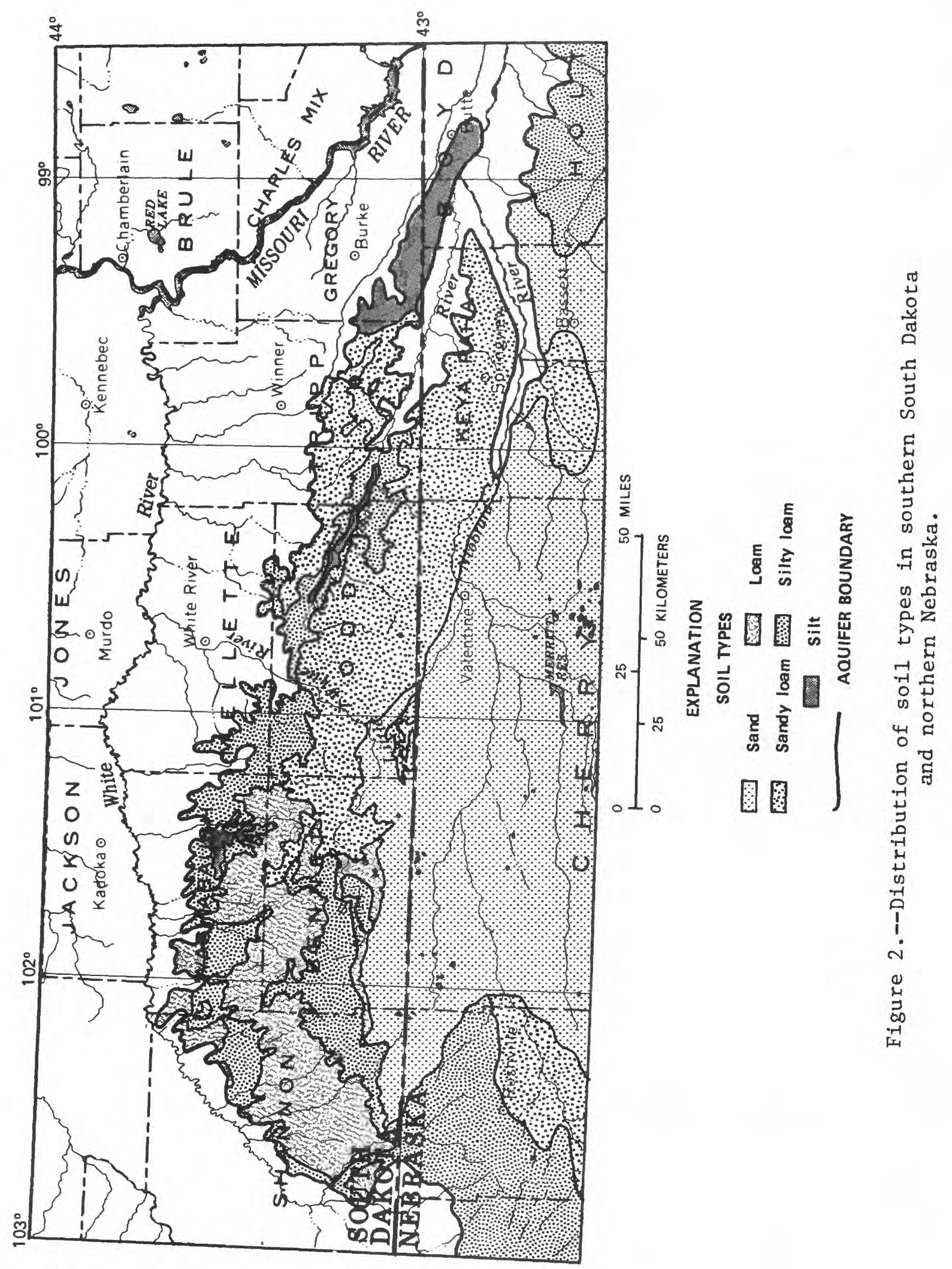


Table 2.--Properties of soil types

\begin{tabular}{ll|cc}
\hline $\begin{array}{l}\text { Soil } \\
\text { type }\end{array}$ & Geomorphology & $\begin{array}{c}\text { Average } \\
\text { hydraulic } \\
\text { conductivity } \\
\text { (inches }\end{array}$ & $\begin{array}{c}\text { Aver hour) } \\
\text { perage } \\
\text { specific yield } \\
\text { (dimensionless) }\end{array}$ \\
\hline Sand--_-- Uplands & $5.0-10.0$ & $0.04-0.09$ \\
Sandy loam---- Uplands & $3.0-9.0$ & $0.06-0.14$ \\
Loam-- Uplands and & $0.7-4.5$ & $0.17-0.19$ \\
Silty loam---- Uplands & $0.8-2.0$ & $0.16-0.19$ \\
Silt-- Uplands & $0.3-0.8$ & $0.16-0.19$ \\
\hline \multicolumn{1}{c}{ lSoils types shown in figure 2. } & & &
\end{tabular}

Normal annual precipitation ranges from about 16 in. at the western end of the study area to about $20 \mathrm{in}$. at the eastern boundary (U.S. Department of Commerce, 1977), and the lines of equal normal annual precipitation generally trend northeast (fig. 3).

Mean pan-evaporation rates of 55 to $60 \mathrm{in./yr}$ (fig. 3) (U.S. Department of Commerce, 1977) infer that the majority of the precipitation probably is either directly evaporated or is evapotranspired. Consequently, only a small part of the precipitation percolates down to the water table. The following recharge estimates were determined by previous investigators: (1) Langbein and others (1949) estimated about 15 percent of the precipitation as recharge or 2.5 to 3.0 in./yr; (2) McGuinness (1963) estimated 1.0 to $2.5 \mathrm{in./yr}$; (3) Bradley (1956) estimated 2.6 in./yr in the Sand Hills; and (4) Rahn and Paul (1975) estimated 3.07 in./yr.

\section{$\underline{\text { Potentiometric Surface }}$}

Water levels were observed from 205 well sites, and a 1980 potentiometric-surface map was generated (fig. 4). The highest heads (greater than $3,400 \mathrm{ft}$ ) occurred along the Nebraska-South Dakota border in the southwestern part of the study area. The lowest heads occurred along the eastern boundary of the aquifer (fig. 4).

The geologic units comprising the High Plains aquifer are structurally flat-lying (dipping less than $1^{\circ}$ ) and regionally continuous. Therefore, the configuration of the potentiometric surface is controlled locally by topography and major streams (Rahn and Paul, 1975; figs. 4 and 5). Ground water flows downgradient from drainage divides that have a relatively high head toward major streams, such as the Little white and the Niobrara Rivers (fig. 5). In areas where major drainages are absent, ground-water flows downgradient to the aquifer boundary (lowest topographic altitude where the aquifer rocks terminate), and discharges as springs and seeps, or by evapotranspiration (fig. 4). 


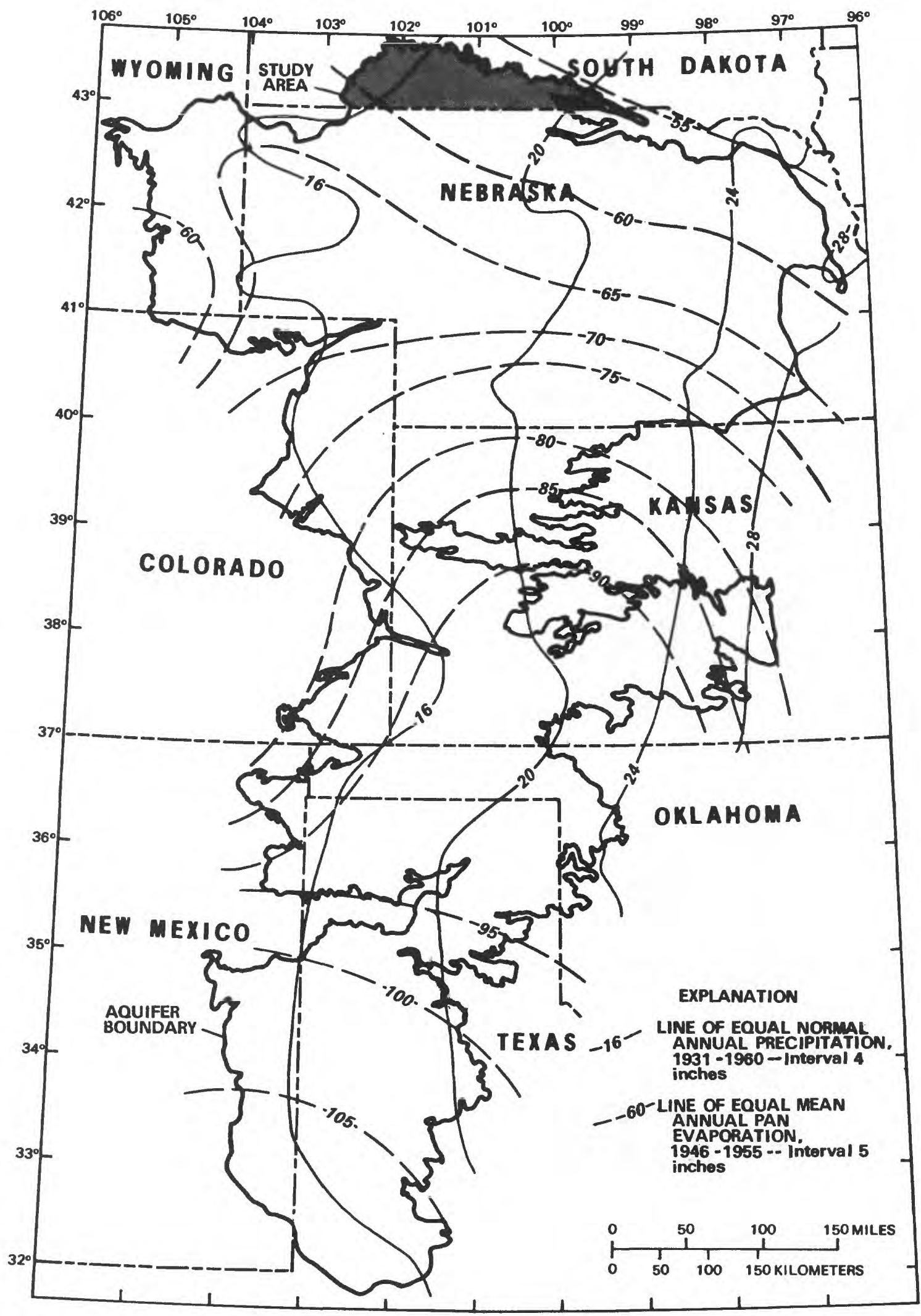

Figure 3.--Normal annual precipitation and mean Class A pan evaporation in the High Plains in the western United States (modified from U.S. Department of Commerce, 1977). 


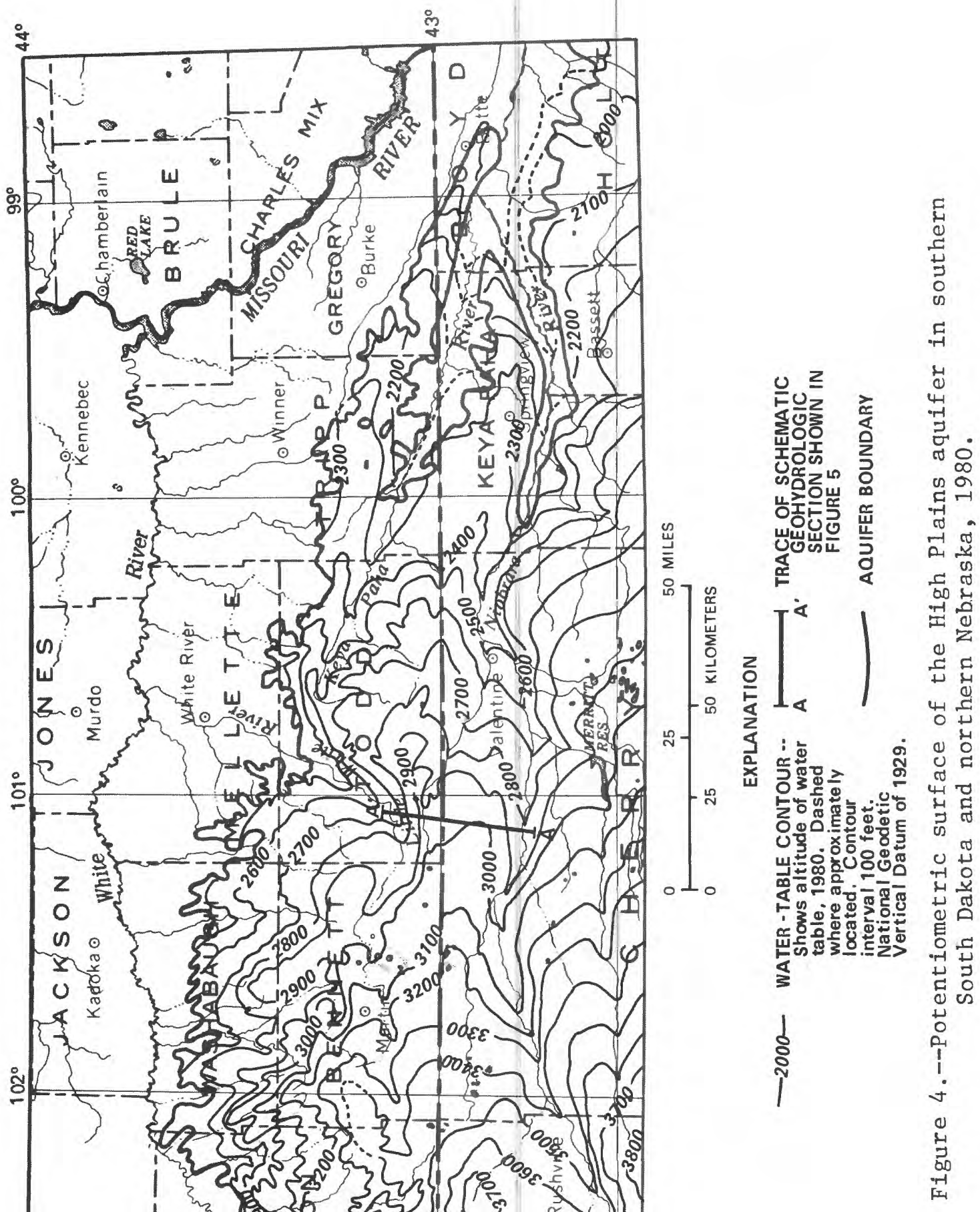




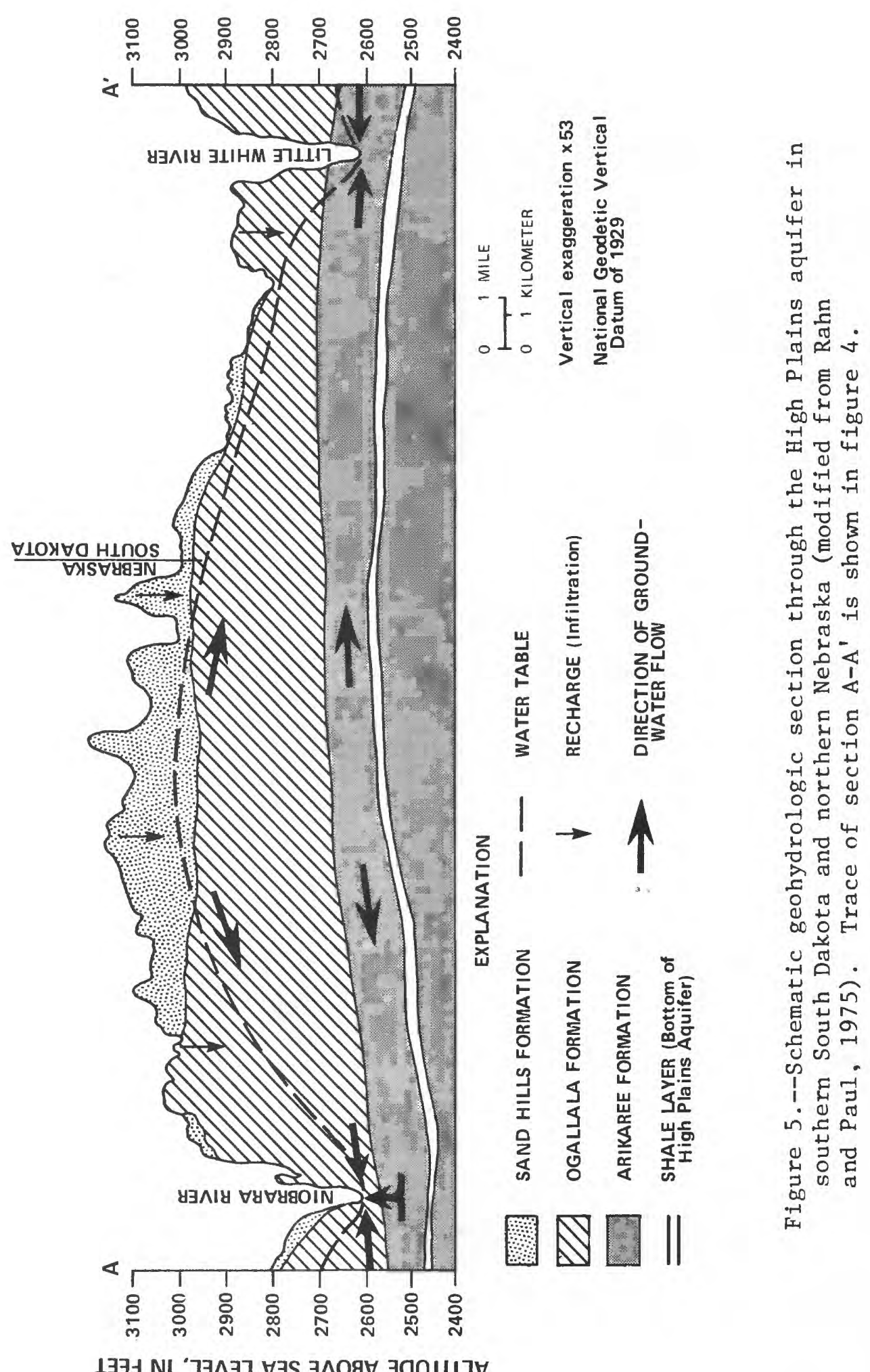

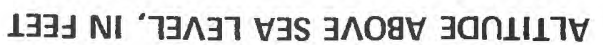




\section{Discharge}

Water-resources data for Nebraska and South Dakota (U.S. Geological Survey, 1980a; 1980b) indicate that along the two major rivers in the region, the Niobrara and the Little White, ground-water discharge sustains streamflow during times of scant precipitation. For example, the Niobrara River has an estimated base flow of $790 \mathrm{ft}^{3} / \mathrm{s}$ near Sparks, Nebr. (Newport, 1959), which represents ground-water discharge from the aquifer plus a 205-ft $3 / \mathrm{s}$ discharge from Merritt Reservoir. Other streams, such as the Keya Paha, are ephemeral, indicating that ground-water discharge is less than evapotranspiration demand during periods of no streamflow, or the level of ground water drops below the bottom of the streams (therefore, there is no ground-water discharge, even if there is no evapotranspiration).

Ground-water consumptive use for irrigation has been estimated from irrigated acreage and crop type to be 940 acre-ft/yr $(1.3 \mathrm{ft} / \mathrm{s})$ in the study area (Kolm and Case, 1983). An estimated 160 wells are used to irrigate approximately 11,100 acres of South Dakota cropland (Gutentag and Weeks, 1980; Heimes and Luckey, 1982).

The third major source of ground-water discharge is springs, seeps, and evapotranspiration along the western, northern, and eastern aquifer boundaries. The large pan-evaporation rates (55 to $60 \mathrm{in./yr}$ ) in these areas indicate that water discharged from the aquifer will be evapotranspired or evaporated rapidly; water seeping through the putcrops and soils is unobservable. For a complete discussion of consumptive-use computations derived from evaporation data, refer to Hargreaves (1966, p. 35-62).

\section{Saturated Thickness}

The depth below land surface to the aquifer base ranges from $600 \mathrm{ft}$ at the southwestern border with Nebraska to $20 \mathrm{ft}$ at the eastern boundary of the study area. The saturated thickness differs greatly between these extremes due to both geologic and hydrologic reasons. The geologic reasons are: (1) The thickness of sandstones in the Arikaree Formation are variable; (2) the contact between the Ogallala Formation and the underlying Arikaree Formation is an undulating erosion surface resulting in large variations in the thickness of the Ogallala Formation (Rahn and Pau1, 1975); (3) the Ogallala erosional surface and variable wind dynamics cause large areal variations in the thickness of the Sand Hills Formation; and (4) recent eolian and fluvial processes have eroded and transported away parłs of the Arikaree, Ogallala, and Sand Hills Formations. The Sand Hills Formation is absent in most areas of South Dakota.

The hydrologic reasons for differences in saturated thickness are: (1) Separate and combined thicknesses of the upper|part of the Arikaree, Ogallala, and Sand Hills Formations are variable throughout the study area; (2) erosion levels of major streams and tributaries are variable; these streams control water-table altitudes which, consequently, control local saturated thicknesses; and (3) recharge and evapotranspiration volumes change gradationally 
from west (less recharge, more evapotranspiration) to east (more recharge, less evapotranspiration).

The greatest saturated thicknesses, 400 to $600 \mathrm{ft}$, occur in the westcentral part of the study area (principally in Bennett County) and comprise about 18 percent of the areal distribution of the aquifer system (fig. 6). The least saturated thicknesses, 0 to $100 \mathrm{ft}$, occur along the northern and eastern limits of the aquifer; they comprise about 44 percent of the areal distribution of the aquifer system (fig. 6). The volume of saturated aquifer material in southern South Dakota is estimated to be 700 million acre-ft (Weeks and Gutentag, 1981).

\section{Hydraulic Conductivity}

Average hydraulic conductivity was estimated, using the methods of Reed and Piskin (Lappala, 1978), from grain-size descriptions obtained from 205 well logs. These values ranged from 3.6 to $160 \mathrm{ft} / \mathrm{d}$, and averaged about $30 \mathrm{ft} / \mathrm{d}$ across the study area (fig. 7).

The lateral distribution of hydraulic conductivity is variable; however, greater estimated values of hydraulic conductivity are distributed in an elongated and sinuous pattern, possibly indicating paleochannel locations (areas with concentrations of coarse sands and gravels) (fig. 7). The paleochannel trends of west-to-east are similar to those near the Black Hills and in other areas of the High Plains.

Transmissivity values were calculated by multiplying hydraulic conductivities by saturated thicknesses. Vertical variability of transmissivity was evaluated from drillers' logs by calculating the first moment (center of gravity) and second moment (variance) of the distribution of transmissivities (Gutentag and Weeks, 1981).

Computations showed that the average relative center of gravity of transmissivity was 0.51 , with a standard deviation of 0.10 , based on the analyses of 205 drillers' logs. This indicated that the weighted transmissivity average can be placed at the center of the aquifer thickness.

\section{Specific Yield}

Average specific yield was estimated from grain size taken from cores and compared with known specific yields for similar materials, as compiled by Johnson (1967). These values ranged from 0 to 25 percent and averaged about 9 percent across the study area (fig. 8).

The distribution of specific-yield values (fig. 8) is similar to that of hydraulic-conductivity values (fig. 7). The elongated and sinuous distribution of larger specific-yield values also may indicate the locations of paleochannels.

Vertical variability of specific yield within drillers' logs was calculated by taking the first (center of gravity) and the second (variance) 


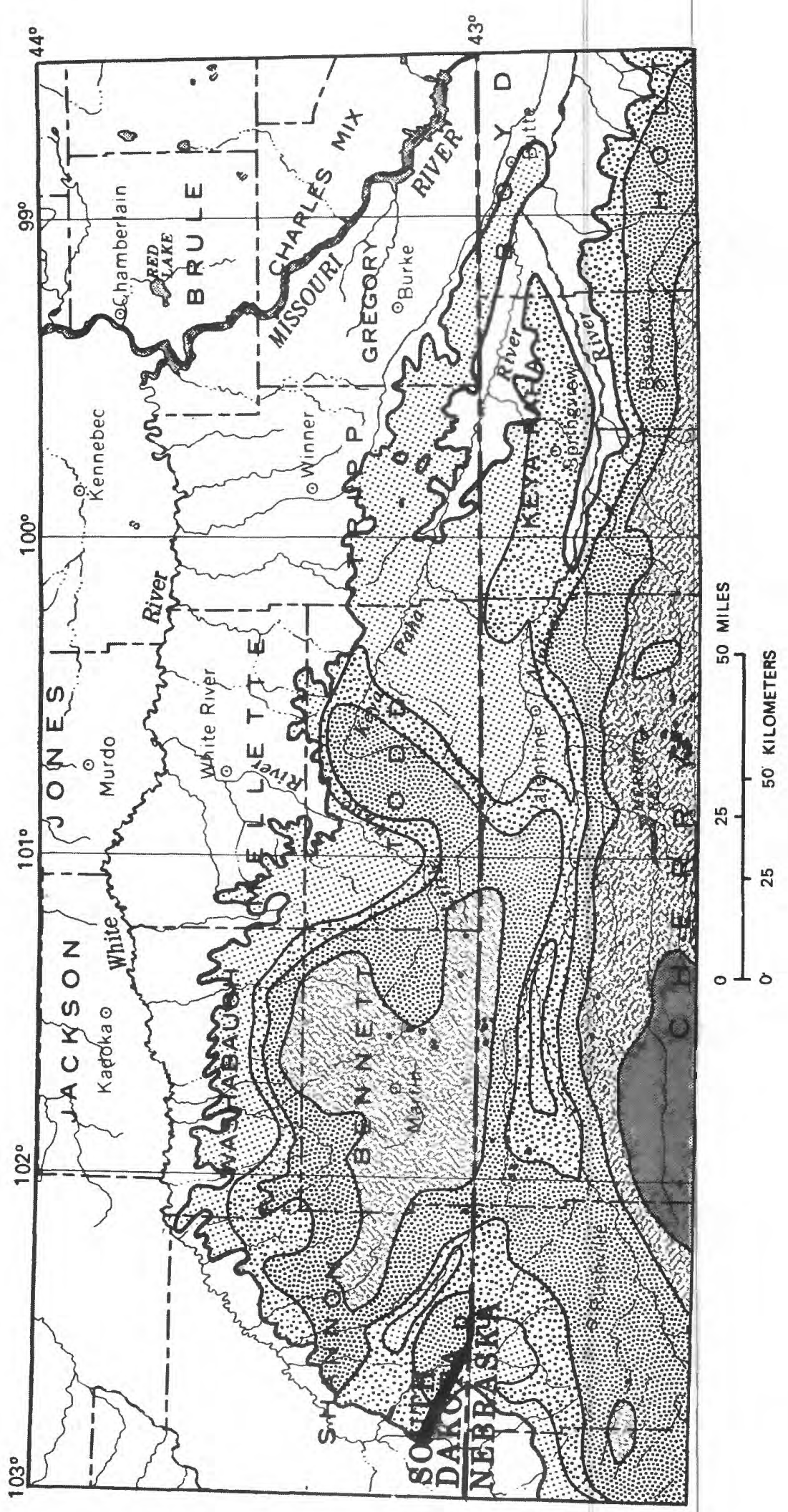

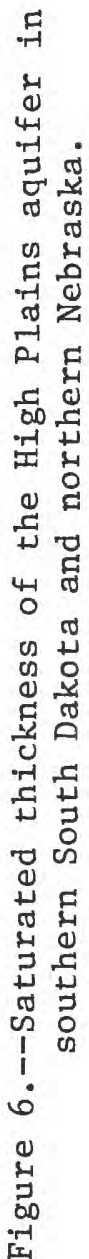




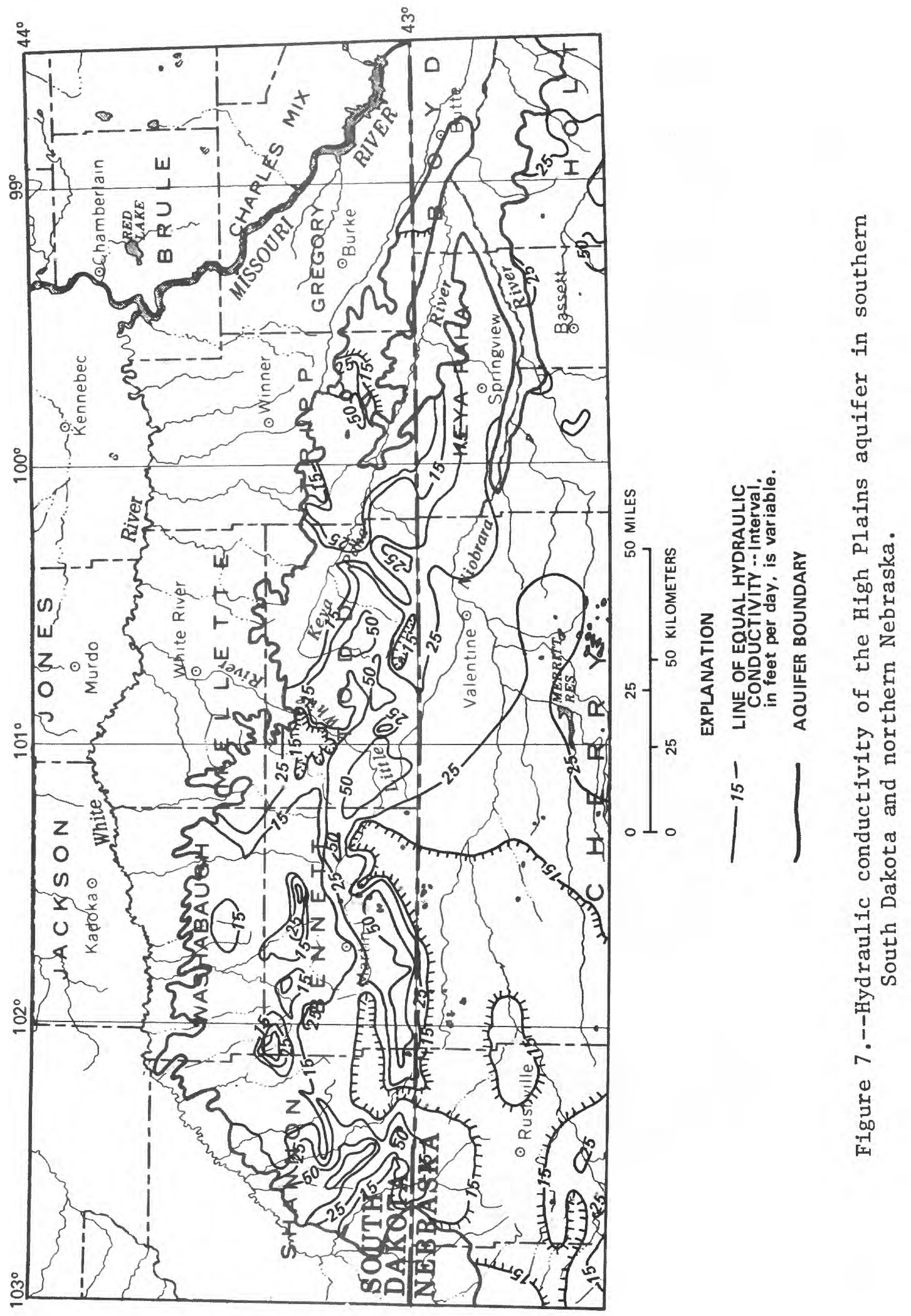




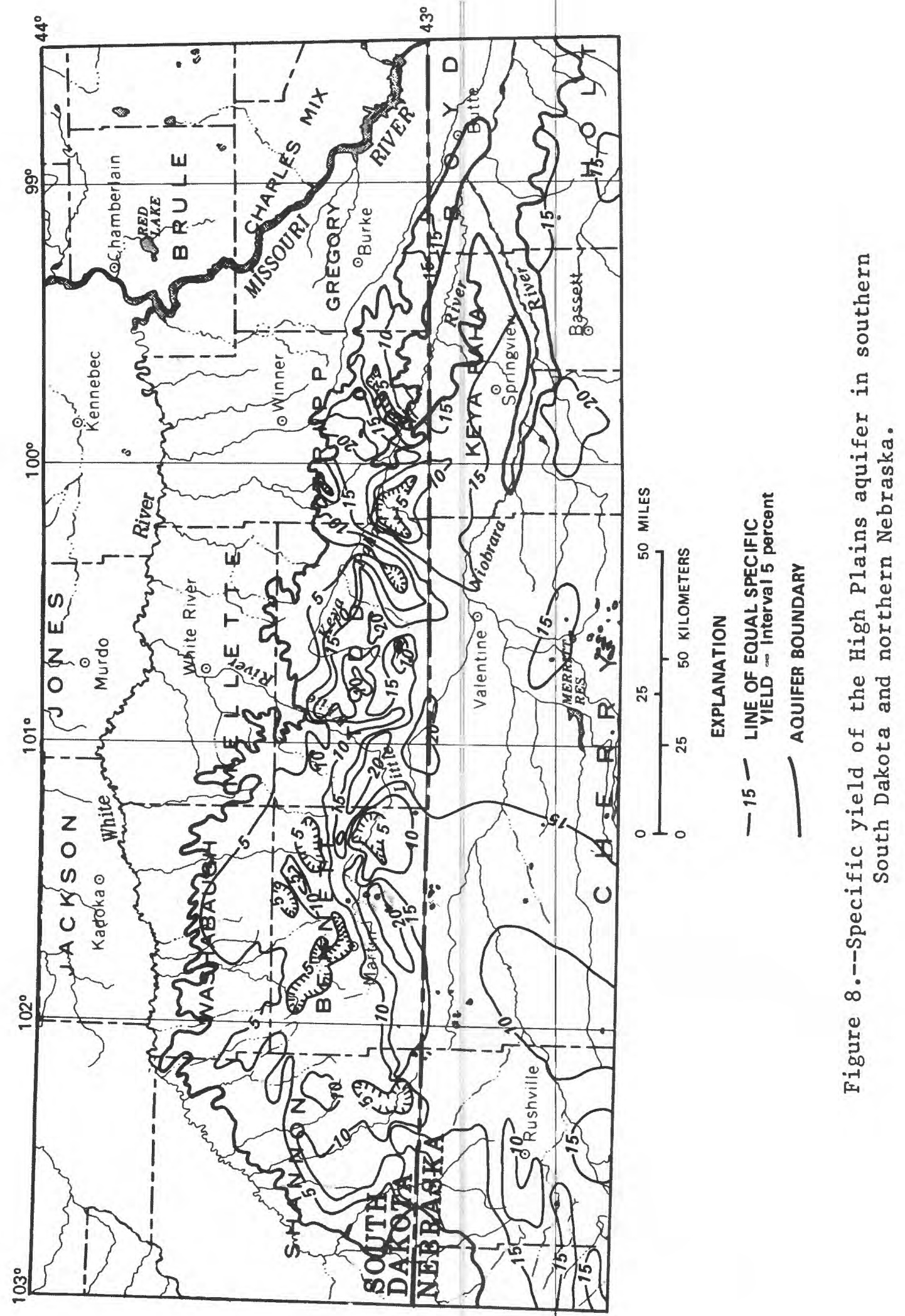


moments of the parameter distribution (Gutentag and Weeks, 1981). The average center of gravity was 0.51 , with standard deviation of 0.19 for the 20.5 logs.

\author{
MODEL SIMULATION
}

Trescott and others (1976) developed a finite-difference model for simulation of two-dimensional ground-water flow in aquifers. The model was designed to simulate the response of an aquifer to stresses, such as pumping, whether the aquifer was artesian, water table, or a combination. The aquifer being modeled may be heterogeneous and anisotropic, and have irregular boundaries. Various recharge and discharge functions also can be simulated by the model, such as leakage from confining beds, interaction with streams, recharge, evapotranspiration, and well discharge. Results from the model simulations are hydraulic heads. Initially, a conceptual model of the aquifer system in southern South Dakota was developed. Data from the conceptual model were incorporated into the final model.

\title{
Model Application
}

\section{Conceptual Mode1}

The conceptual model of the High Plains aquifer in southern South Dakota and northern Nebraska was derived from analyses of aquifer characteristics discussed in the earlier sections. To summarize, the unconfined aquifer consists of three hydraulically connected rock units: the Sand Hills Formation, the Ogallala Formation, and the upper sandstone units of the Arikaree Formation. Shale beds near the top of the Arikaree Formation define the base of the aquifer for the model (fig. 5). Recharge in the area is primarily by infiltration of precipitation through the soil to the underlying aquifer. The potentiometric surface (fig. 4) indicates that the water moves laterally from the interior of the study area to the western, northern, or eastern aquifer boundaries, or locally towards major stream valleys. Ground water is discharged through springs and seeps, or into streams. Because of negligible ground-water development from the High Plains aquifer in southern South Dakota and northern Nebraska, the aquifer was assumed to be in a steady-state condition.

Vertical components of ground-water flow, except near the discharge areas, are assumed to be small compared to horizontal components because the value of vertical hydraulic conductivity is much smaller than that of lateral hydraulic conductivity, and because there is no evidence of vertical leakage from stratigraphically lower aquifers (for example, the Dakota aquifer). Therefore, it was assumed that two-dimensional flow could represent the ground-water flow in the High Plains aquifer in southern South Dakota and northern Nebraska. 


\section{Data Preparation}

Five maps were prepared to show (or document) the following: (1) Precipitation (fig. 3); (2) potentiometric surface (fig. 4); (3) saturated thickness (fig. 6); (4) hydraulic conductivity (fig. 7); and (5) specific yield (fig. 8). Each map consisted of point values, which were contoured at selected intervals. An average value of each parameter was then estimated from these contoured maps for each grid node of the model. These estimated average values were used as initial model input for simulation.

Saturated-thickness, specific-yield, potentiometric-surface, and hydraulic-conductivity contour maps for north-central Nebraska were prepared in a separate study by Pettijohn and Chen (1982). Parts of these maps were used in this study, and average values of each parameter were estimated from their maps for each grid node of the model as initial model input data.

\section{Grid Geometfy}

The study area was divided into a block-centered, finite-difference grid with variable node spacings (fig. 9). Two nodal sizes were established: $31 / 3$ by $5 \mathrm{mi}$ in the western two-thirds of the study area, where spatial changes in transmissivity were greatest, and 5 by $5 \mathrm{mi}$ in the eastern one-third of the study area. The nodal expansion in the X-direction ( $31 / 3$ to $5 \mathrm{mi}$ ) has a ratio of less than 1.5 to avoid large truncation errors and convergence problems (Trescott and others, 1976).

\section{Boundaries, Recharge, and Evapotranspiration}

Most of the physical boundaries of the High Plains aquifer in southern South Dakota are geologically defined. To minimize boundary effects in the area of study (fig. 9), the model boundary was extended southward about $30 \mathrm{mi}$ into northern Nebraska.

The applied computer model requires a no-flow boundary inserted around the model border (Trescott and others, 1976). Constant-head boundaries were inserted within the model at nodes where ground water entered or exited from the aquifer system without change in heads. For example, the western, northern, and eastern boundaries of the South Dakota study area are regions of discharge and, therefore, were given constant-head nodes (fig. 9). Most of the nodes along the southern model boundary in Nebraska represent areas of ground-water flow into the model and also were assigned as constant heads.

Nodes representing reaches of major riyers where hydraulic connection occurs, such as the Little White River, the Niobrara River, and the Keya Paha River, were represented by leaky river nodes (fig. 9). The alluvial material present in these river valleys is predominantly clay or silty-clay. Therefore, a confining-layer hydraulic conductivity value of $1 \mathrm{ft} / \mathrm{d}$ was used to simulate flow from the aquifer through the alluvium (confining layer) to the river. It was assumed that the controlling, confining clay layer averages $10 \mathrm{ft}$ thick. Most alluvium covers about one-tenth the area of most 


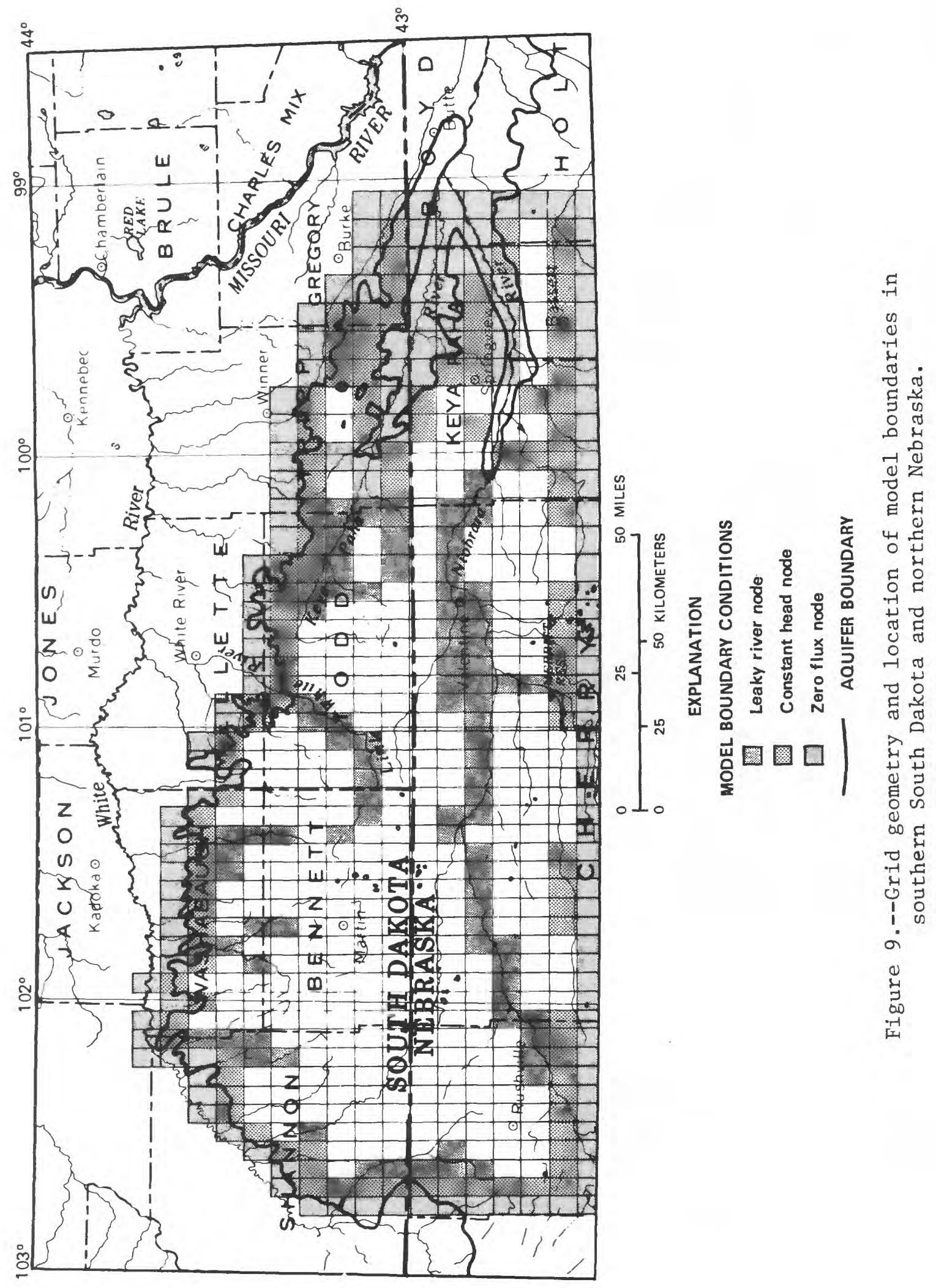


river nodes; therefore, the hydraulic-conductivity value used in the calibrated model was $0.1 \mathrm{ft} / \mathrm{d}$.

Recharge was estimated to be 8 percent of the precipitation ( 1.3 to $1.8 \mathrm{in.} / \mathrm{yr}$ ). Most of the soils were moderately-to-very permeable ( $\mathrm{fig}, 2$, table 2). The eastern part of the study area has less permeable soils, but also has greater precipitation and lesser evapotranspiration than the western areas. Therefore, recharge in the eastern parts was considered to be the same or slightly greater than that of the western parts of the study area.

The effective depth of evapotranspiration was estimated to be $10 \mathrm{ft}$. Because the water table usually is greater than $10 \mathrm{ft}$ below land surface, evapotranspiration was not considered in the model. However, the estimated recharge rate is the net recharge which excludes the evapotranspiration.

\section{Model Calibration Results}

The model was calibrated by a trial-error method--adjusting the model parameters--to obtain a best fit of computed heads to observed heads under predevelopment steady-state conditions. Because it was a steady-state simulation, the values of specific yield were not needed and were set to zero.

The Strongly Implicit Procedure (SIP) was used to solve the flow finitedifference equations, and the iteration parameter was set to 1.00 (five iteration parameters were sequentially tested beginning with 0 and terminating with 0.9992). Eighteen iterations were necessary to obtain the final solution. The closure error of computed head between two iterations was set to be $0.01 \mathrm{ft}$.

The model was not used to simulate transient conditions, because groundwater development has not caused significant water-level changes in the study area; therefore, information is insufficient on water-level changes for transient calibration. The model could be used to simulate transient conditions for qualitative interpretations, if the estimated specific yields were input into the model. However, transient calibrations are necessary before the model may be used for prediction of head changes during development.

\section{Mass Balance}

Annual recharge from precipitation computed by the model, was 539,000 acre-ft $\left(744 \mathrm{ft}^{3} / \mathrm{s}\right)$, and the inflow through constant-head nodes was 113,000 acre-ft $\left(156 \mathrm{ft}^{3} / \mathrm{s}\right)$. Therefore, the total inflow into the aquifer was 652,000 acre-ft $\left(900 \mathrm{ft}^{3} / \mathrm{s}\right)$.

Annual discharge from the aquifer computed by the model was 648,000 acre-ft, of which 513,000 acre-ft $\left(709 \mathrm{ft}^{3} / \mathrm{s}\right)$ discharged along streams, and 135,000 acre-ft $\left(187 \mathrm{ft}^{3} / \mathrm{s}\right)$ discharged as seepage or springs along the boundary. The percent difference between computed recharge and discharge was -0.56 . 


\section{Potentiometric Surface}

Computed heads were contoured manually as shown in fig. 10. The potentiometric surface drawn from calculated heads (fig. 10) compares wel1 with the potentiometric surface drawn from observed water levels (fig. 4). Heads computed at well nodes also compare well with the water level observed in wells (fig. 11), indicating that the model was well calibrated.

The residuals of heads (difference between computed and observed heads) are shown in fig. 12. The majority of the residuals that exceeded $30 \mathrm{ft}$ were located in the model interior (fig. 12), where saturated thickness generally is greater than $300 \mathrm{ft}$. The maximum positive residual was 59.90 $\mathrm{ft}$, and the maximum negative residual was $-59.72 \mathrm{ft}$. The mean was $-0.998 \mathrm{ft}$, and the standard deviation was $25.54 \mathrm{ft}$, indicating that 67 percent of the computed heads were within $26 \mathrm{ft}$ of observed heads. A11 the nodes for which water-level measurements are available had head residuals within one standard deviation of the mean residual.

\section{Boundary Conditions}

Discharge calculated by the model at constant-head nodes rarely exceeded $10 \mathrm{ft}^{3} / \mathrm{s}$ in areas where ground-water seepage occurs along the nonstream aquifer boundaries. This discharge, which occurs within a minimum area of $16.7 \mathrm{mi}^{2}$, represents a net value of $8.1 \mathrm{in./yr}$. Because the pan-evaporation rate is greater than $55 \mathrm{in./yr}$ in the study area, this discharge probably does not occur as springs or major seeps, unless unique geologic conditions are present, such as fracture zones.

Discharge, calculated by the model at leaky river nodes along streams, was compared with measured streamflow data (U.S. Geological Survey, 1980a; 1980b). The lowest average 7-day flow during 1980 occurred during July or August when the evapotranspiration rate was greatest. Consequently, ground water that was discharged from the aquifer along streams was assumed to be greater than these measured stream discharges.

Daily discharge records are available for the Little White River, the Keya Paha River, and the Niobrara River (U.S. Geological Survey, 1980a; $1980 \mathrm{~b})$. The Little White River is used extensively in irrigation projects, and water is stored in a series of dams or canals. Flow in one reach of the channe1, which is not regulated, was measured at $10 \mathrm{ft}^{3} / \mathrm{s}$ during August 1980. At this 1ocation, the model computed ground-water discharge from the aquifer to be $21 \mathrm{ft}^{3} / \mathrm{s}$. It was assumed that $11 \mathrm{ft}^{3} / \mathrm{s}$ probably was discharged directly as evapotranspiration.

The Keya Paha River ceases to flow during periods in August and September because of evapotranspiration. The leaky-river nodes along this river and its tributaries simulated the discharge from the aquifer to be $24 \mathrm{ft}^{3} / \mathrm{s}$. It was assumed that the entire discharge from the aquifer probably was lost to evapotranspiration. 


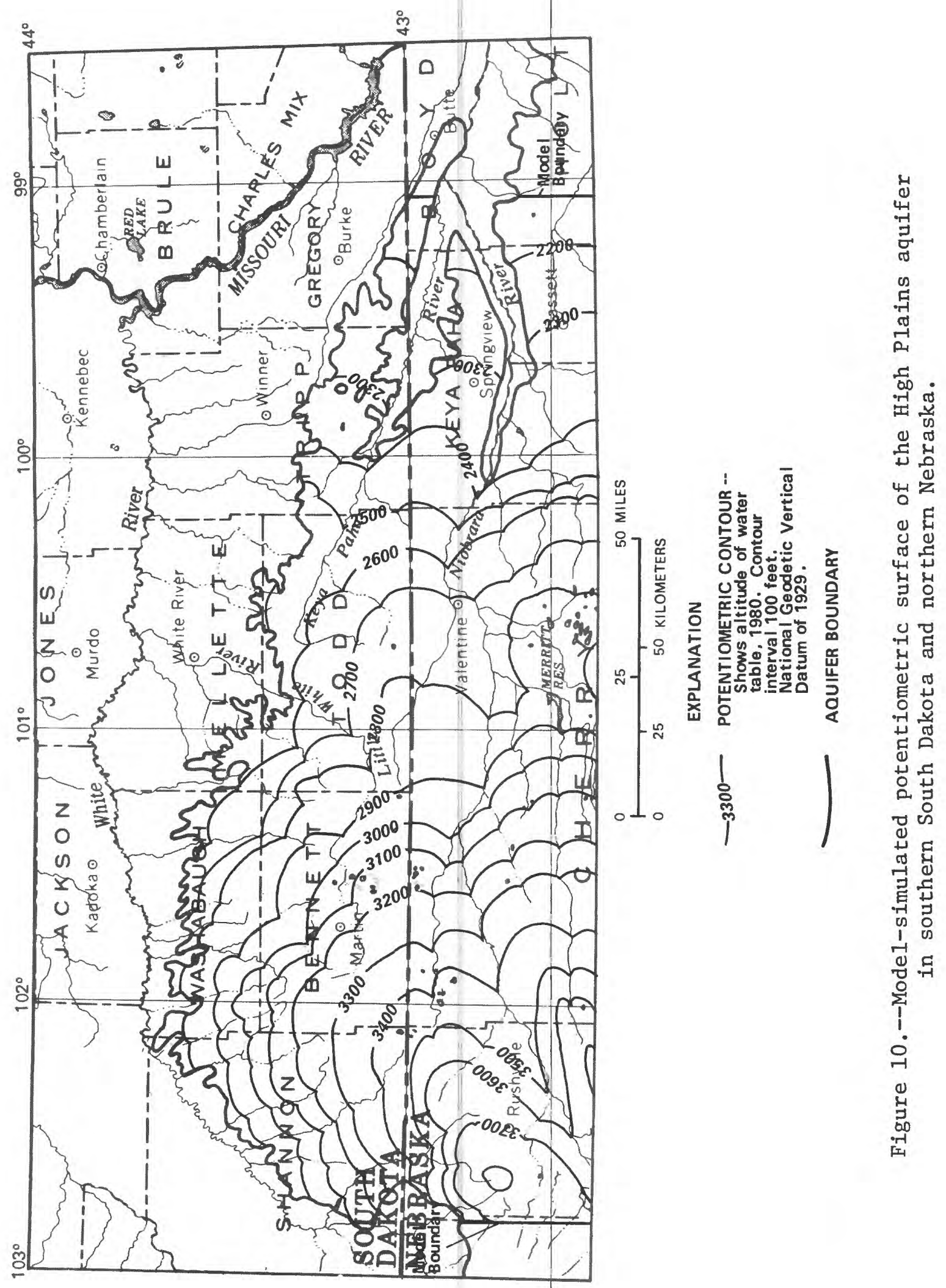




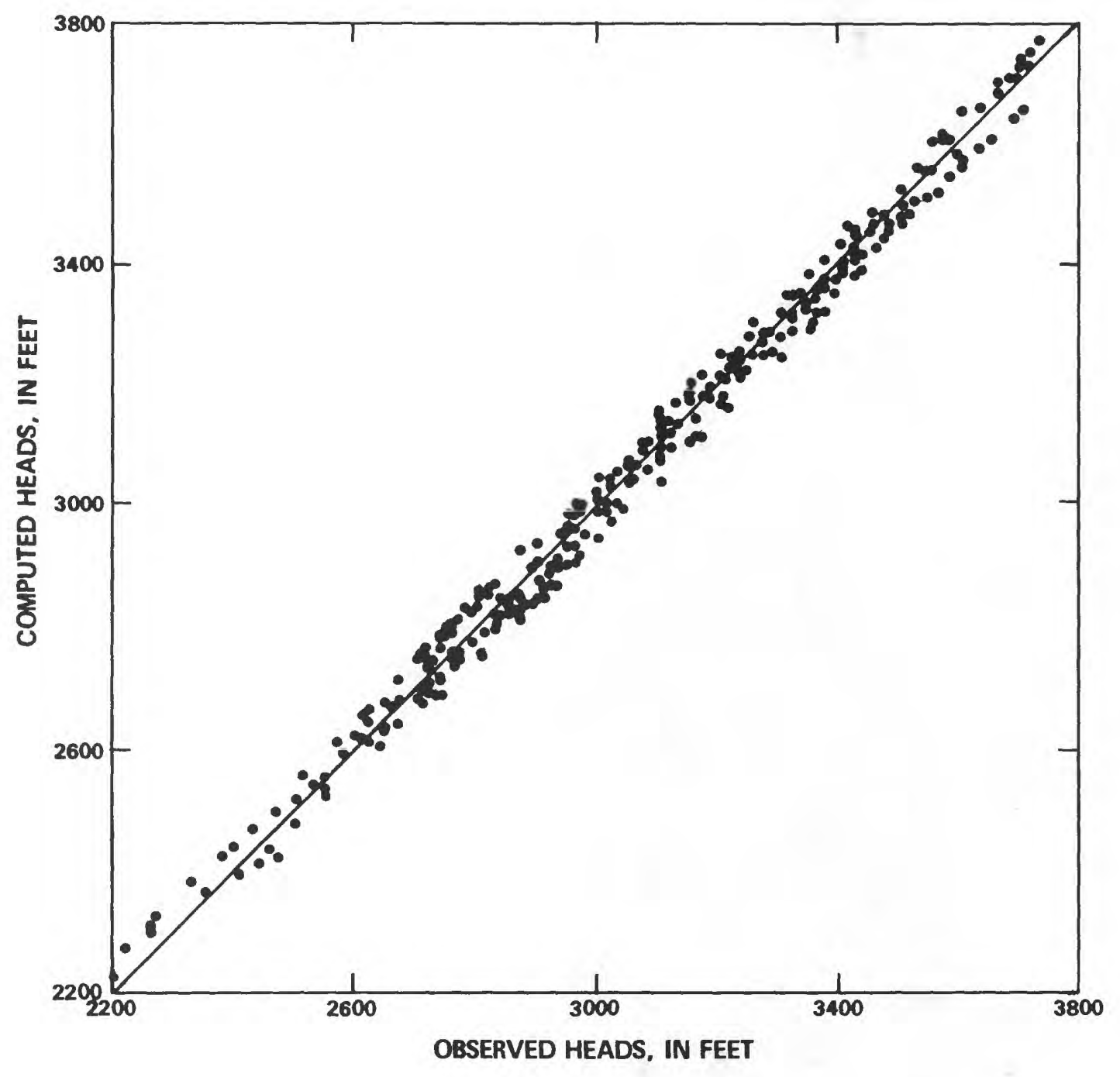

Figure 11.--Comparison between computed and measured heads for the calibrated model of the High Plains aquifer in southern South Dakota and northern Nebraska. 


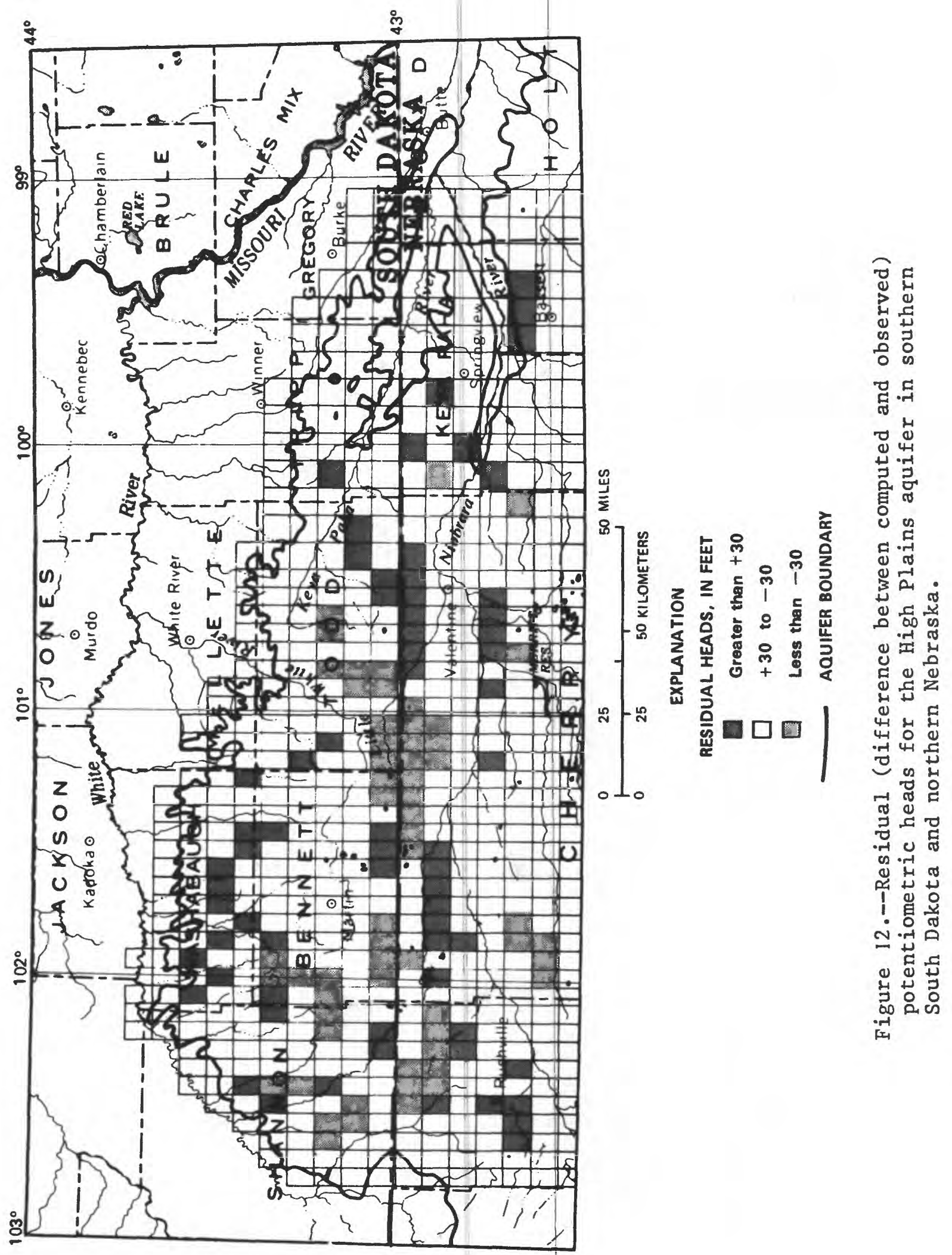


The Niobrara River has an estimated base flow during winter months, when there is negligible evapotranspiration, of $790 \mathrm{ft}^{3} / \mathrm{s}$ near sparks, Nebr. (Newport, 1959). Sparks is about $18 \mathrm{mi}$ downstream from Valentine, Nebr. This discharge is equivalent to the total volume of ground water discharged from the High Plains aquifer to the Niobrara River between Box Butte Reservoir (south of Rushville, Nebr., out of study area) and Sparks, Nebr., and to the Snake River (Niobrara tributary) below Merritt Reservoir. This base flow value also includes a $205-\mathrm{ft}^{3} / \mathrm{s}$ discharge from Merritt Reservoir; therefore, the actual ground-water discharge is about $585 \mathrm{ft} / \mathrm{s}$.

The model area includes only that part of the Niobrara River between Gordon, Nebr., and Sparks, Nebr., and the lower part of the Snake River downstream from Burge, Nebr. (Gordon is about $15 \mathrm{mi}$ northeast of Rushville). Discharge records (U.S. Geological Survey, 1980a) show that the Niobrara River has an average flow of $110 \mathrm{ft}^{3} / \mathrm{s}$ (in November) near Gordon, Nebr., and that the Snake River has an average flow of $25 \mathrm{ft}^{3} / \mathrm{s}$ (in November, independent of reservoir contributions). Therefore, the volume of ground water discharged from the High Plains aquifer to the Niobrara River was estimated to be $450 \mathrm{ft}^{3} / \mathrm{s}$ in the study area [585 minus $(110+25)$ ]. The discharge calculated for the 44 leaky-river nodes placed along this section of the Niobrara River is $363 \mathrm{ft}^{3} / \mathrm{s}$ (difference of approximately $2 \mathrm{ft}^{3} / \mathrm{s}$ per node).

The other minor streams in the area, which have been modeled with leakyriver nodes, are intermittent during the summer months. Calculated groundwater discharge to these streams ranges from 2.7 to $11.0 \mathrm{in./yr}$. These rates are small and most of the discharge is assumed to be lost to evapotranspiration.

The above comparisons should be interpreted qualitatively, not quantitatively, because the steady-state simulation represents a long-term average discharge from the aquifer and the used stream records indicate the flow only a couple of months in a year. Generally, the simulated ground-water discharge into streams seems reasonable as compared with stream records.

\section{Sensitivity Analysis}

Because models present nonunique solutions when simulating hydrologic systems, sensitivity of aquifer parameters to head changes need to be considered. After model calibration, boundary conditions, hydraulic conductivities, and recharge rates were adjusted significantly (one after the other and by holding other parameters constant) to determine the sensitivity of the model as indicated by magnitude of changes in computed heads. The best calibration was indicated by the lowest standard deviation of observed versus computed heads; a mean residual between -1.0 and $1.0 \mathrm{ft}$, a minimum residual of $-60.0 \mathrm{ft}$, and a maximum residual of $+60.0 \mathrm{ft}$ were obtained. 
To test the sensitivity of the model to changes in hydraulic conductivity, the standard deviations (based upon 513 active nodes) of the computed versus observed heads were compared between the calibrated model and the simulations in which the hydraulic conductivity was increased or decreased for all nodes simultaneously by 33 percent (fig. 13A and 13B). As an example, if a node had a hydraulic conductivity of $20 \mathrm{ft} / \mathrm{d}$ in the calibrated model, $26.6 \mathrm{ft} / \mathrm{d}$ was used in a separate simulation to test the effect of increased hydraulic conductivity, and $13.4 \mathrm{ft} / \mathrm{d}$ was used in another simulation to test the effect of decreased hydraulic conductivity (all other parameters were held constant).

The data in figure $13 \mathrm{~A}$ and $13 \mathrm{~B}$ indicate that: (1) The standard deviation increased from 25.54 to $31.34 \mathrm{ft}$ when hydraulic conductivity was increased by 33 percent; and (2) the standard deviation increased from 25.54 to $37.33 \mathrm{ft}$ when hydraulic conductivity was decreased by 33 percent. These small increases in standard deviation indicate that 33 percent changes in hydraulic conductivity are relatively insensitive in this model.

\section{Recharge Rates}

To test the sensitivity of recharge rates, the standard deviations (based upon 513 active nodes) of the computed versus observed heads were compared between the calibrated model and the simulations in which the recharge rate was increased or decreased by 33 percent across the entire study area (fig. 13C and 13D). For example, if a node has a recharge rate of $1.8 \mathrm{in./yr}$ in the calibrated model, recharge rates of 1.2 and $2.4 \mathrm{in}$./yr were used in the two sensitivity simulations.

The data in figures $13 \mathrm{C}$ and $13 \mathrm{D}$ indicate that: (1) The standard deviation increased from 25.54 to $31.23 \mathrm{ft}$ when recharge was increased by 33 percent; and (2) the standard deviation increased from 25.54 to $35.21 \mathrm{ft}$ when recharge was decreased by 33 percent. These small increases in standard deviation also indicate that 33 percent changes in recharge are insensitive in this model.

\section{Boundaries}

Two questions regarding the southern model boundary (Nebraska) needed to be answered: (1) Was the model boundary placed far enough south so that boundary effects would not influence the model results in the South Dakota study area; and (2) is it critical to simulate the southern model boundary with constant-head or constant-flux nodes? To answer these questions, the following sensitivity analyses were completed: (1) The model was redone with all the southern boundary nodes changed from constant-head to constantflux nodes; the values of constant flux used were those calculated as constant heads in the calibrated model; and (2) the model was then redone twice more with increased and decreased constant flux at the southern boundary. The values of constant flux used were uniformly increased or uniformly 


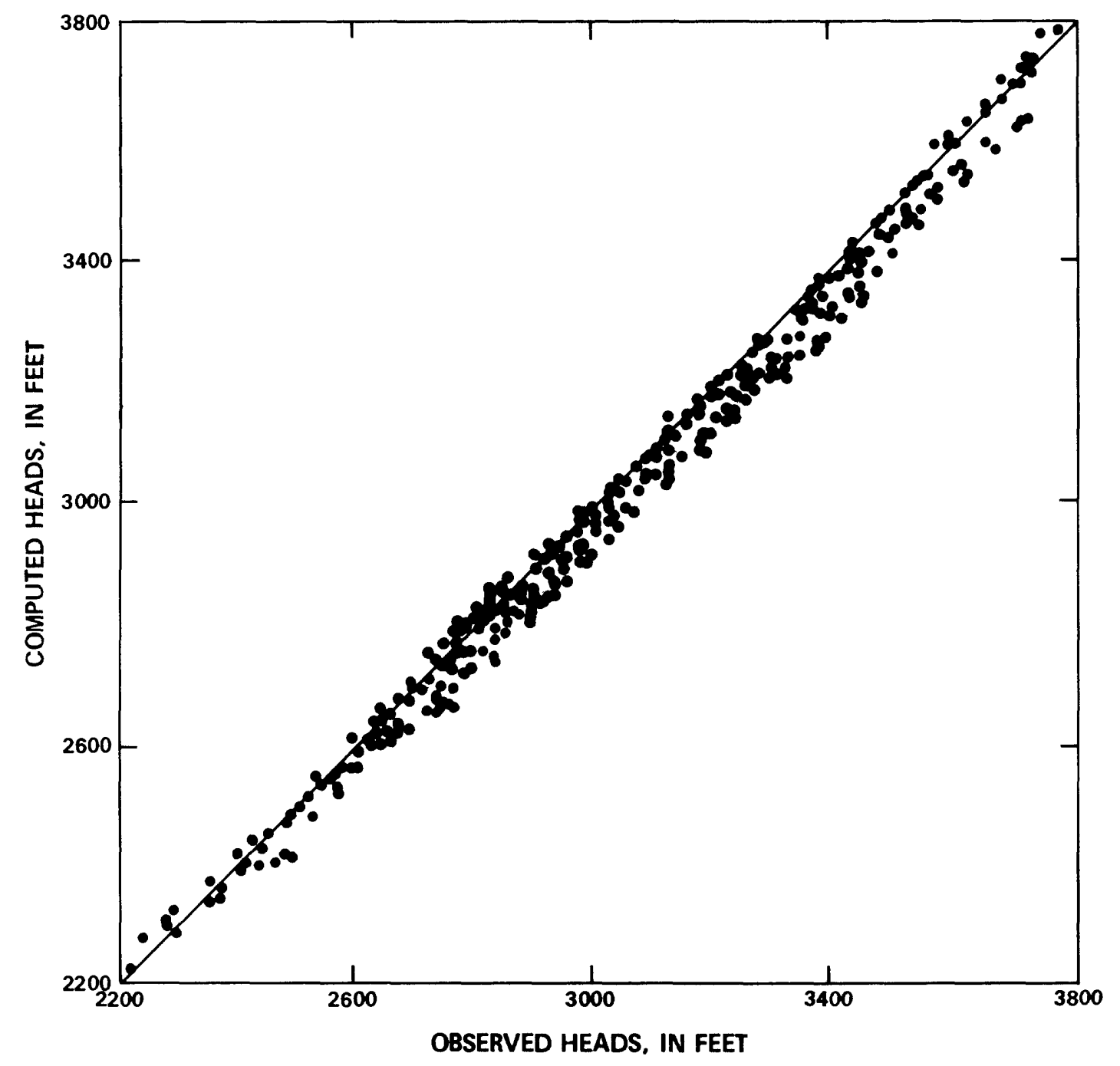

Figure 13A.--Sensitivity of the model to changes in recharge rate and hydraulic conductivity noted in the comparisons between computed and observed heads for the High Plains aquifer in southern South Dakota and northern Nebraska: hydraulic conductivity increased by 33 percent. 


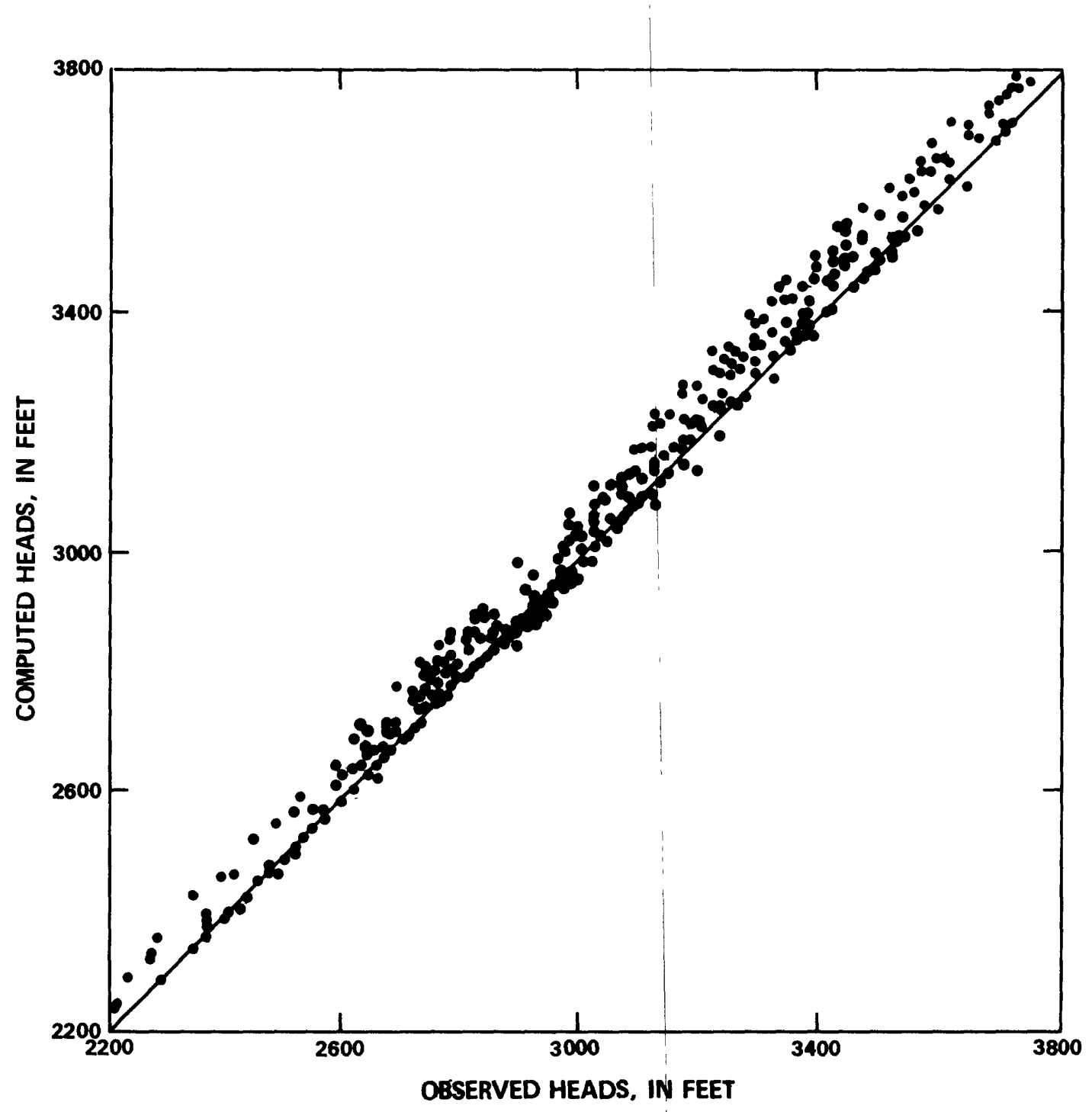

Figure 13B.--Sensitivity of the model to changes in recharge rate and hydraulic conductivity noted in the comparisons between computed and observed heads for the High Plains aquifer in southern South Dakota and northern Nebraska: hydraulic conductivity decreased by 33 percent. 


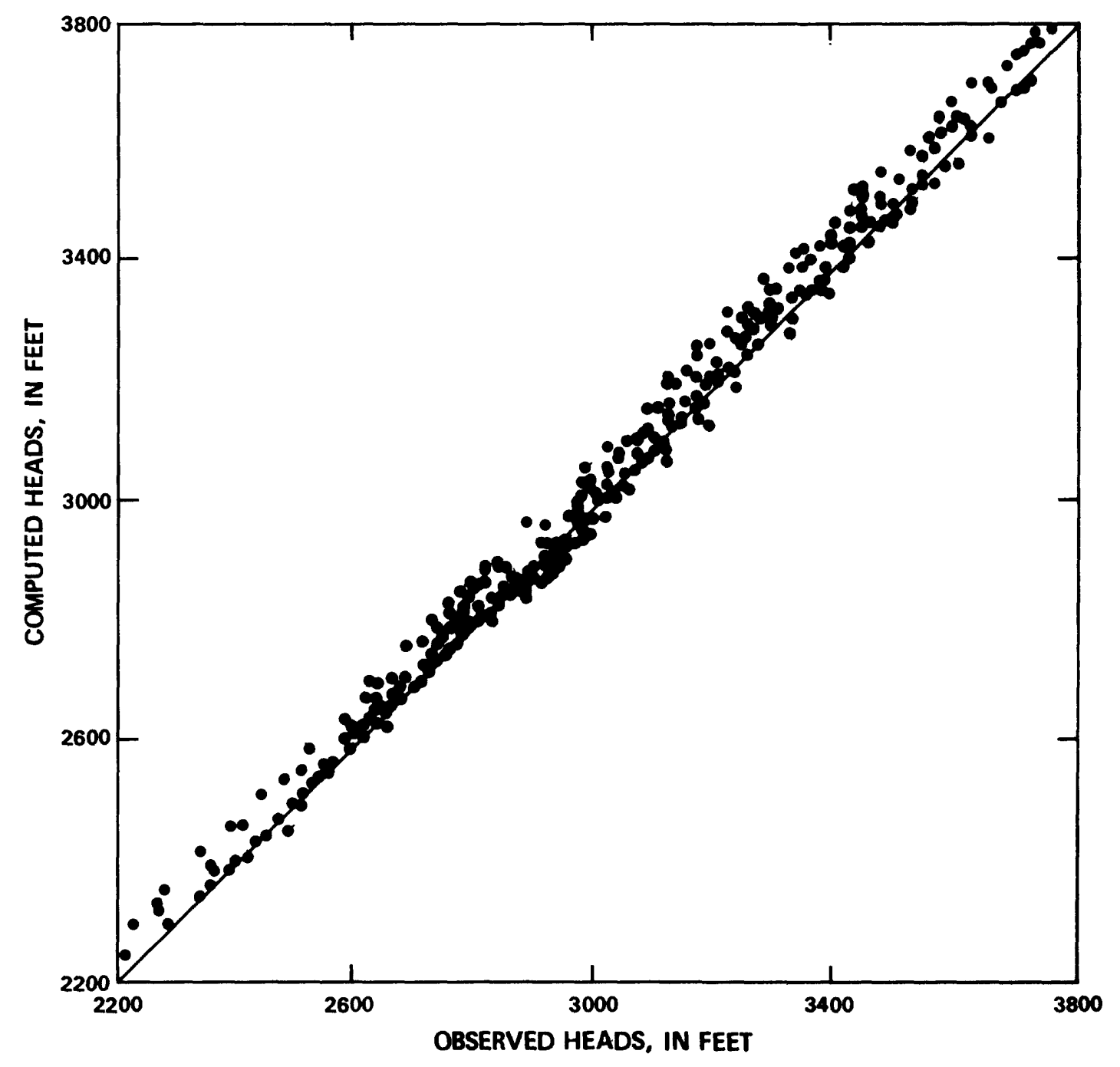

Figure 13C.--Sensitivity of the model to changes in recharge rate and hydraulic conductivity noted in the comparisons between computed and observed heads for the High Plains aquifer in southern South Dakota and northern Nebraska: recharge increased by 33 percent. 


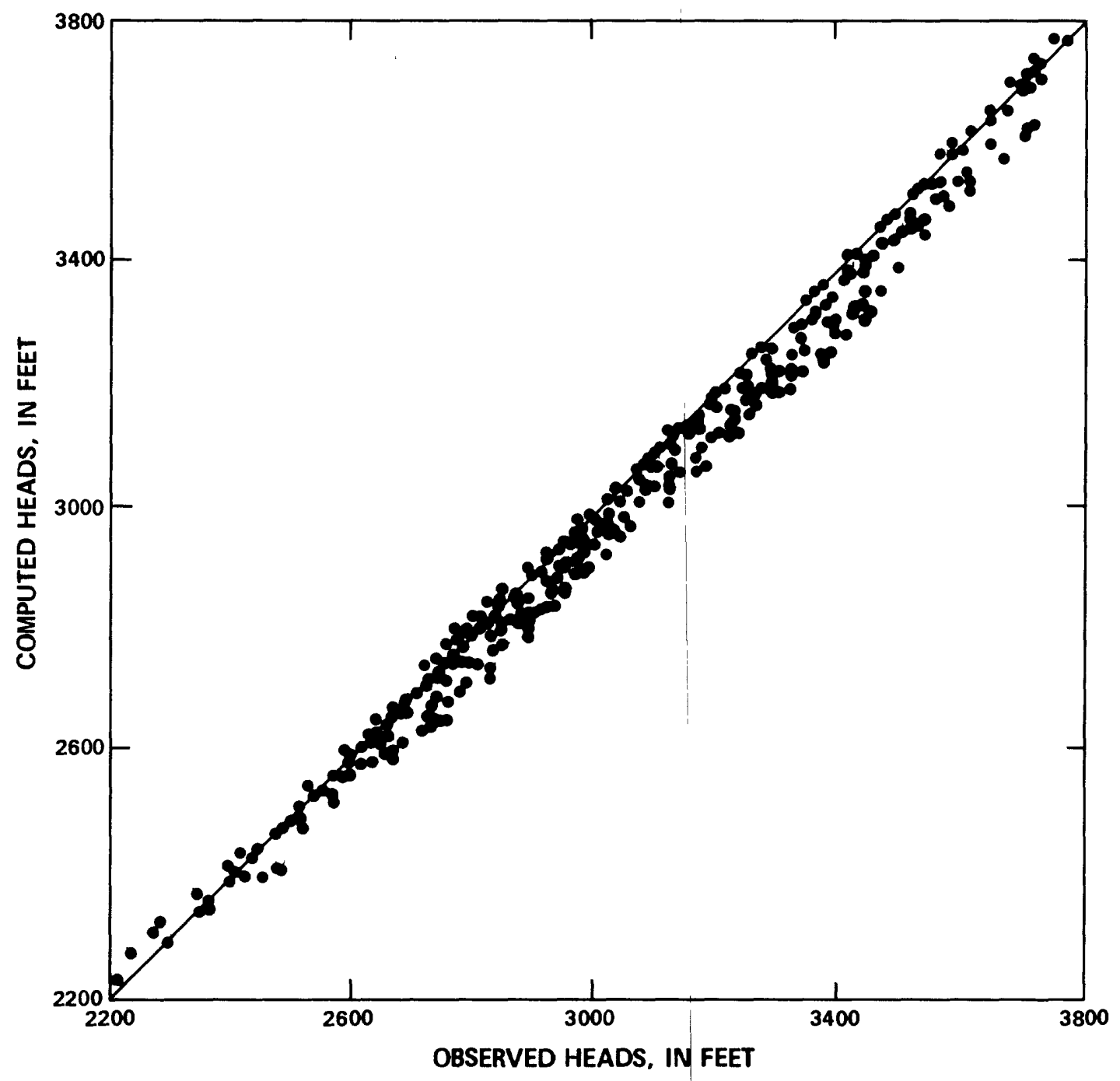

Figure 13D.--Sensitivity of the model to changes in recharge rate and hydraulic conductivity noted in the comparisons between computed and observed heads for the High Plains aquifer in southern South Dakota and northern Nebraska: recharge decreased by 33 percent. 
decreased by 33 percent from those calculated at constant-head nodes in the calibrated model.

Results showed that, in all cases, no residual head changes in South Dakota exceeded $4 \mathrm{ft}$. Furthermore, with the exception of two nodes located in southwestern South Dakota and the southwestern part of the model area in Nebraska, virtually all the boundary effects imposed by the constant-flux nodes were confined to an area south of the Niobrara River. This indicates that the southern model boundary was placed far enough to the south of the South Dakota study area so that boundary effects are minimal, and there was no significant difference in heads near the boundary whether the boundary was simulated as constant head or constant flux.

\section{SUMMARY AND CONCLUSIONS}

This study simulated and evaluated the geohydrology of the unconfined High Plains aquifer in southern South Dakota by using a two-dimensional, finite-difference, computer model. The aquifer is composed of the flat-lying, uppermost sandstone units of the Tertiary Arikaree Formation, and the Tertiary Ogallala and Quaternary Sand Hills Formations, and has an area of 5,290 $\mathrm{mi}^{2}$.

Recharge to the aquifer is primarily by direct infiltration of precipitation through the soils and stabilized sand dunes. The annual recharge rate was estimated to be 8 percent of the precipitation rate, or about $1.3 \mathrm{in}$./yr in the west and $1.8 \mathrm{in./yr}$ in the the east. The recharge rate is a small percentage of precipitation, primarily because of significant evapotranspira-

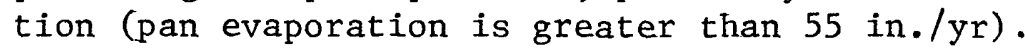

Ground-water movement is from the west-central part of the study area to the western, northern, and eastern outcrop areas, where the water is discharged. Locally, streams near the aquifer boundary and the major rivers have eroded 300 to $400 \mathrm{ft}$ into the Arikaree, Ogallala, and Sand Hills Formations, resulting in hydraulic connection with the aquifer.

Saturated thickness of the aquifer ranges from 0 to $600 \mathrm{ft}$, and the volume of saturated aquifer material was estimated to be 700 million acreft. Hydraulic conductivity was estimated to range from less than 10 to $160 \mathrm{ft} / \mathrm{d}$ and averaged about $30 \mathrm{ft} / \mathrm{d}$. Specific yield was estimated to range from 0 to 25 percent and averaged about 9 percent across the study area. Because the depth of the local and intermediate flow systems is small compared to the extent of the regional aquifer system, vertical flow was assumed to be negligible and the aquifer was simulated in two dimensions.

A variable grid ( $31 / 3$ by $5 \mathrm{mi}$ and 5 by $5 \mathrm{mi}$ ) finite-difference computer model of the aquifer was calibrated to simulate steady-state flow conditions. Grid axes were oriented east-west and north-south. Model boundaries were simulated using constant-head nodes around the model perimeter, where groundwater discharges from the system (at the western, northern, and eastern boundaries), or enters the system (at the southern model boundary). Leakyriver nodes were placed along major rivers and some tributaries where 
hydraulic connection occurs. River-discharge records were compared with ground-water discharges simulated by the model to check the model results.

The model, which was calibrated for steady-state conditions, had a maximum head residual (difference between computed and observed heads) of less than $60 \mathrm{ft}$; the mean head residual was $-1.0 \mathrm{ft}$. Two-thirds of the computed heads were within $26 \mathrm{ft}$ of observed heads. The potentiometric surface constructed from computed heads reasonably matched the potentiometric surface constructed from water-level data, indicating that the model probably can simulate the flow system in the study area in a steady-state condition. Data were not available to calibrate the model for transient conditions, due to limited aquifer development.

Sensitivity analyses revealed that simulated heads were insensitive to 33-percent changes (increase and decrease) in hydraulic conductivity and recharge rates. The low standard deviation of computed versus observed heads indicated that values used for recharge and hydraulic conductivity probably are reasonable; the small increases in standard deviation due to sensitivity analyses indicated that 33-percent estimation errors in hydraulic conductivity and recharge rate probably are not critical to model results.

\section{SELECTED REFERENCES}

Blaney, H. F., and Criddle, W. D., 1962, Determining consumptive use and irrigation water requirement: U.S. Agricultural Research Service Technical Bulletin no. 1275, 59 p.

Bradley, Edward, 1956, Geology and ground-water resources of the upper Niobrara River basin, Nebraska and Wyoming: U.S. Geological Survey Water-Supply Paper 1368, $70 \mathrm{p}$.

Dunham, R. J., 1961, Geology of uranium in Chadron area, Nebraska and South Dakota: U.S. Geological Survey open-file report, one sheet, scale $1: 48,000$.

E11is, M. J., Adolphson, D. G., and Ficken, J. G., 1972, Basic hydrogeologic data, Rosebud Indian Reservation, South Dakota: South Dakota State Geological Survey Water Resources Report no. 6, 111 p.

Feder, G. L., and Krothe, N. C., 1981, Results of a reconnaissance waterquality sampling program of the Ogallala aquifer in Colorado, Kansas, Nebraska, Oklahoma, South Dakota, and Texas: U.S. Geological Survey Water-Resources Investigations $81-65,7 \mathrm{p}$.

Gutentag, E. D., and Weeks, J. B., 1980, Water table in the High Plains aquifer in 1978 in parts of Colorado, Kansas, Nebraska, New Mexico, Oklahoma, South Dakota, Texas, and Wyoming: U.S. Geological Survey Hydrologic Investigations Atlas, HA-642.

1981, Evaluating vertical variability of transmissivity and specific yield for the High Plains regional aquifer system [abs.]: Geological Society of America Abstracts with Programs, Rocky Mountain Section, v. 13, no. 4, p. 199 . 
Hargreaves, G. H., 1966, Consumptive use computations from evaporation pan data, in Methods for estimating evapotranspiration: American Society of Civil Engineers Irrigation and Drainage Specialty Conference, Las Vegas, Nevada, 1966, Proceedings, p. 35-62.

Harksen, J. C., and MacDonald, J. R., 1969, Guidebook to the major Cenozoic deposits of southwestern South Dakota: South Dakota Geological Survey Guidebook 2, 103 p.

Heimes, F. J., and Luckey, R. R., 1980, Evaluating methods for determining water use in the High Plains in parts of Colorado, Kansas, Nebraska, New Mexico, Oklahoma, South Dakota, Texas, and Wyoming; 1979: U.S. Geological Survey Water-Resources Investigations 80-111, 125 p. 1982, Method for estimating historical irrigation requirements from ground water in the High Plains in parts of Colorado, Kansas, Nebraska, New Mexico, Oklahoma, South Dakota, Texas, and Wyoming: U.S. Geologica1 Survey Water-Resources Investigations 82-40, $68 \mathrm{p}$.

Johnson, A. I., 1967, Specific yield--Compilation of specific yield for various materials: U.S. Geological Survey Water-Supply Paper 1662-D, p. D1-D74.

Kolm, K. E., and Case, H. L, III, 1983, Evaluation of techniques for identifying irrigated crop types and estimating acreages from Landsat imagery in the High Plains of South Dakota: Photogrammetic Engineering and Remote Sensing [in press].

Krothe, N. C., and Oliver, J. W., 1982, Sulfur isotopic composition and water chemistry in water from the High Plains aquifer, Oklahoma Panhandle and southwestern Kansas: U.S. Geological Survey Water-Resources Investigations $82-12,32 \mathrm{p}$.

Krothe, N. C., Oliver, J. W., and Weeks, J. B., 1982, Dissolved solids and sodium in water from the High Plains aquifer in parts of Colorado, Kansas, Nebraska, New Mexico, Oklahoma, South Dakota, Texas, and Wyoming: U.S. Geological Survey Hydrologic Investigations Atlas HA-658.

Langbein, W. B., and others, 1949, Annual runoff in the United States: U.S. Geological Survey Circular 52, 14 p.

Lappala, E. G., 1978, Quantitative hydrogeology of the Upper Republican Natural Resources District, southwest Nebraska: U.S. Geological Survey Water-Resources Investigations 78-38, 209 p.

Luckey, R. R., Gutentag, E. D., and Weeks, J. 'B., 1981, Water-1eve1 and saturated-thickness changes, predevelopment to 1980 , in the High Plains aquifer in parts of Colorado, Kansas, Nebraska, New Mexico, Oklahoma, South Dakota, Texas, and Wyoming: U.S. Geological Survey Hydrologic Investigations Atlas HA-652.

Lugn, A. L., 1938, The Nebraska State Geological Survey and the "Valentine problem": American Journal of Science, 5th series, v. 36, no. 213, p. 220-227.

McGuinness, C. L., 1963, The role of ground water in the national water situation: U.S. Geological Survey Water-Supply Paper 1800, 1121 p.

Newport, T. G., 1959, Ground-water resources of the lower Niobrara River and Ponca Creek basins, Nebraska and South Dakota: U.S. Geological Survey Water-Supply Paper 1460-G, $50 \mathrm{p}$.

Pettijohn, R. A., and Chen, H. H., 1982, Hydraulic conductivity, specific yield, and pumpage--High Plains aquifer system, Nebraska: U.S. Geological Survey Water-Resources Investigations 82-4014, 20 p. 
Pinder, G. F., 1969, An iterative digital model for aquifer evaluation: U.S. Geological Survey open-file report, $43 \mathrm{p}$.

Prickett, T. A., and Lonnquist, C. G., 1971, Selected digital computer techniques for ground-water resources evaluation: Illinois State Water Survey Bulletin 55, 62 p.

Rahn, P. H., and Paul, H. A., 1975, Hydrology of a portion of the Sand Hills and Ogallala aquifer, South Dakota and Nebraska: Ground Water, v. 13, no. 5, p. 428-437.

Sevon, W. D., 1960, Geology of the Spring Creek quandrangle, South Dakota: South Dakota State Geological Survey Geologic Map, scale 1:62,500.

Trescott, P. C., 1973, Iterative digital model for aquifer evaluation: U.S. Geologica1 Survey open-file report, $18 \mathrm{p}$.

Trescott, P. C., Pinder, G. F., and Larson, S. P., 1976, Finite-difference model for aquifer simulation in two dimensions with results of numerical experiments: U.S. Geological Survey Techniques of Water-Resources Investigations, Book 7, Chapter 1, $116 \mathrm{p}$.

U.S. Department of Commerce, 1977, Climatic atlas of the United States: Environmental Sciences Services Administration, Environmental Data Service, $80 \mathrm{p}$.

U.S. Geological Survey, 1980a, Water resources data for Nebraska: U.S. Geological Survey Water-Resources Data Report NE-80-1, 471 p. 1980b, Water resources data for South Dakota: U.S. Geological Survey Water-Resources Data Report SD-80-1, $454 \mathrm{p}$.

Weeks, J. B., 1978, Plan of study for the High Plains regional aquifer system analysis in parts of Colorado, Kansas, Nebraska, New Mexico, Oklahoma, South Dakota, Texas, and Wyoming: U.S. Geological Survey Water-Resources Investigations $78-70,32 \mathrm{p}$.

Weeks, J. B., and Gutentag, E. D., 1981, Bedrock geology, altitude of base, and 1980 saturated thickness of the High Plains aquifer in parts of Colorado, Kansas, Nebraska, New Mexico, Oklahoma, South Dakota, Texas, and Wyoming: U.S. Geological Survey Hydrologic Investigations Atlas HA-648. 